\title{
Evaluation of 2018 initial teacher training programs
}

\author{
Özgür Ulubey ${ }^{* a}$, Semra Başaran ${ }^{* *_{a}}$ \\ ${ }^{a}$ Muğla Sıtkı Koçman Unversity, Faculty of Education, Muğla/Turkey
}

\begin{tabular}{ll} 
Article Info \\
\hline DOI: 10.31704/ijocis.2019.012 \\
\hline Article History: \\
Received $\quad 11$ July 2019 \\
Revised $\quad 27$ August 2019 \\
Accepted $\quad$ 01 October 2019 \\
Online $\quad$ 26 December 2019
\end{tabular}

Keywords:

Teacher training,

Curriculum development,

Curriculum evaluation.

Article Type:

Research paper

\begin{abstract}
The aim of this study is to evaluate the initial teacher training programs updated in 2018 in Turkey. In the study, the basic interpretive research design was used. Participants of the study were 32 faculty members from different programs in a faculty of education of a university in the western part of Turkey. Data were collected via face to face interviews using semistructured interview form. Findings of the study generally revealed that 2018 initial teacher training programs were not prepared in line with curriculum development principles. The faculty members think that the changes in the programs cannot meet the needs of qualified teacher training. They recommended updating the teacher training programs in line with the curriculum development principles, increasing the weekly course hours, adding the implementation hours in the courses and adding the school experience course back to the programs.
\end{abstract}

\section{8 öğretmen yetiştirme lisans programlarının değerlendirilmesi}

\begin{tabular}{ll}
\multicolumn{2}{l}{ Makale Bilgisi } \\
\hline DOI: $10.31704 /$ ijocis.2019.012 \\
\hline Makale Geçmişi: \\
Geliş & 11 Temmuz 2019 \\
Düzeltme & 27 Ağustos 2019 \\
Kabul & 01 Ekim 2019 \\
Çevrimiçi & 26 Aralık 2019
\end{tabular}

Anahtar Kelimeler:

Öğretmen yetiştirme,

Program geliştirme,

Program değerlendirme.

\section{Makale Türü:}

Özgün Makale

\section{Öz}

Bu çalışmada Türkiye'de 2018 yılında güncellenen öğretmen yetiştirme lisans programlarının değerlendirilmesi amaçlanmıştır. Çalışmada nitel araştırma desenlerinden temel yorumlayıcı desen kullanılmıştır. Araştırmanın katılımcıları, Türkiye'nin batı bölgesinde yer alan bir üniversitenin eğitim fakültesinde farklı programlarında görevli 32 öğretim üyesidir. Veriler yarı yapılandırılmış görüşme formunun kullanıldığı yüz yüze görüşmeler ile toplanmıştır. Öğretim üyelerinden elde edilen veriler tümevarımsal içerik analizi yaklaşımı ile çözümlenmiştir. Araştırmanın bulguları 2018 öğretmen yetiştirme lisans programlarının genel olarak program geliştirme ilkelerine uygun bir şekilde hazırlanmadığı göstermiştir. Öğretim üyeleri, programlardaki değişikliklerin nitelikli öğretmen yetiştirme ile ilgili ihtiyaçları karşılayamayacağını düşünmektedirler. Programların program geliştirme ilkeleri gözetilerek güncellenmesini, haftalık ders saatlerinin arttırılmasını, derslere uygulama saatlerinin eklenmesini ve okul deneyimi dersinin programa geri eklenmesini önermektedirler.

\footnotetext{
* Author: oulubey@mu.edu.tr 


\section{Introduction}

It can be said that the scientific, economic and cultural development of societies and the quality of the trained teachers are mutually dependent (Cruickshank et al., 1996; Darling-Hammond, 2006; TEDMEM, 2014; Yıldırım, 2013). Training qualified teachers is among the major objectives of the Republic of Turkey in the field of education as in other countries. To do so, initial teacher training programs are revised and updated according to the requirements of the current period. Apart from Village Institutes, which were practiceoriented and educated teachers for the development of the society, it is not possible to say that this aim has been achieved fully (Atanur-Baskan, 2001; Safran, 2014; Yıldırım 2011).

Prior to 1982 primary school teachers were trained at First Teacher Training Schools, Education Institutes, Village Teacher Training Courses, Village Teacher Schools and Village Institutes (Altunya, 2005; Ataünal, 1987; Ataünal, 1994; Cicioğlu, 1983; Ministry of National Education [MoNE], 1995; Öztürk, 1996; Öztürk, 1998; Öztürk, 2005; Özalp and Ataünal, 1977; Higher Education Council [HEC], 1998). Middle school teachers were trained at Education Institutes, Higher Teacher Schools, Trial Higher Teacher Schools and universities (Kavcar, 2002; Oğuzkan, 1983; Şahin, 2006; Tambağ, 2007; Uçan, 1982; HEC, 1998). Prior to education faculties being the sole responsible for teacher training there were differing teacher training sources. With the transfer of the duty of teacher training to universities in 1982, academic studies on educational sciences and teacher training have started to be carried out in faculties of education (HEC, 2007).

Being the sole source of teacher training faculties of education initiated comprehensive updates and restructuring of the system was initiated in 1997 via the National Education Development Project supported by the World Bank. In this restructuring endeavour, some undergraduate programs of educational sciences were closed on the grounds that they were dysfunctional. With the transition to the eight-year compulsory education, school levels were organized as eight-year primary and three-year secondary education. The faculties of education and the curricula were reviewed and restructured to meet the requirements of compulsory primary education. Teacher competencies were emphasized and practices were added to courses. By this way pre-service teachers were expected to reinforce their knowledge and skills related to teaching in a real environment. With the minor programs, pre-service teachers were provided with opportunities to gain competences in different fields of teaching (HEC, 1998, 2007, 2018). However, these programs were not accepted due to the lack of emphasis on theoretical courses and the fact that they caused pre-service teachers to be qualified only about general culture and content knowledge. Eşme (1998), evaluating the 1997 structuring, did not find the departmental structures realistic and criticized the program by stating that the quality of the faculties of education would decrease, that the content of the courses would be dysfunctional due to the non-thesis master's degree programs and that the degrees from minor programs would create difficulties in employment. Kavcar (2003) stated that the new structuring would cause problems in training field teachers and urgent measures should be taken in this regard. Ataman (1998) stated that longitudinal teacher training experiences were not taken into consideration in these revisions.

The teacher training undergraduate programs were revised again so as to fulfil the needs in 2006 . The structure of the education faculties changed and professional knowledge courses were embedded to the curricula. The number of general culture courses in the programs was increased and education faculties were authorized to determine $25 \%$ of the courses they deemed necessary. The $50-60 \%$ of the program was allocated to content knowledge, $25-30 \%$ to pedagogical content knowledge and $15-20 \%$ to general culture. This meant increase of general culture and elective courses and decrease of practice-oriented courses (HEC, 2007, 2018). The goal was to equip teacher candidates with intellectual qualifications that teachers need to possess. It was also stated that the new programs coincided with the European Union teacher training programs (HEC, 2007b). Teacher training undergraduate programs implemented as of 2006-2007 academic year were revised again in 2018. As a result of the evaluations, it was stated that the content knowledge and pedagogical content knowledge courses should be redesigned and more emphasis should be given to them in the programs. It was also pointed out that the undergraduate programs training middle school field teachers showed differences among faculties. Great emphasis was put on ensuring the compliance of the programs with official documents such as General Competencies of Teaching Profession and Teacher Strategy, the 10th Development Plan, Ministry of National Education (MoNE) 2015-2019 Strategic Plan, Turkey Higher Education Qualifications Framework (THEQF), Teacher Training and Educational Sciences Content Competences. It was stated that there was a need for further reforms in line with Bologna guidelines especially via accreditation studies in the faculties of education. The objectives such as forming common elective courses pool to be offered in different 
teacher training programs, training of pre-service teachers ready for versatile roles and qualified enough to be good researcher teachers (HEC, 2018).

It was stated that the updated teacher training undergraduate programs were prepared in three stages: creation of program development commissions, conducting field surveys and carrying out the program updating process. It was stated that during the program development process, commissions consisting of three to five members were formed for each undergraduate program. Further commissions were also formed for Pedagogical Content Knowledge and General Culture Courses. The commissions had meetings with alumni, parents, school principals, teachers and faculty members. It was emphasized that the qualifications stated under the Teacher Training and Educational Sciences field of Turkish Higher Education Qualifications Framework and Teacher Competencies developed by the MoNE were examined. It was stated that firstly the courses that would be removed from, combined with and added to the 2006 teacher training programs were determined, and then the names, content, weekly course hours and credits (local credits and ECTS) of the courses to be included in the new programs were updated. The opinions of the MoNE were first received about the draft programs and then submitted to the Teacher Training Working Group and finally approved by the Higher Education Council (HEC). During the updating process of the programs, workshops and meetings were organized with the stakeholders of education from different parts of Turkey. The innovations in the 2018 undergraduate programs can be summarized as follows: In the programs, $30-35 \%$ of the curriculum was allocated to pedagogical content knowledge courses, $15-20 \%$ to general culture courses and $45-50 \%$ to content knowledge courses (HEC; 2018). A core program common to different teacher training programs was formed and pedagogical content knowledge courses were revised. The names of the courses such as "Introduction to Education, Scientific Research Methods were changed but the names of the courses such as Classroom Management, Teaching Principles and Methods, Educational Psychology have remained the same but weekly hours have been decreased. School Experience course was removed from the programs and extended to two terms as Teaching Practice Course I and II. Sociology of Education, History of Turkish Education, and Philosophy of Education were included as common courses in all the teacher training programs. It was also stated that in addition to the elective courses stated in the programs, depending on the interests, wishes and requirements of the students a maximum of six courses could be added to the elective courses pool of pedagogical content knowledge and content knowledge with the approval of the HEC and courses could be added to the general culture elective courses by the approval of the university senate. The updated teacher training programs were put into effect in the 2018-2019 academic year with first-year students.

Education programs enable the determination of the characteristics of individuals to be educated for a society. Quality of the programs is one of the most important requirements for the quality of education because poor quality programs cannot ensure a quality education (Gözütok, 2001). It is possible to ensure high quality of the programs via evaluations carried out at regular intervals (Erden, 1998). Program evaluation is defined as "a process in which information about the effectiveness of a designed and implemented training program is collected, analyzed and interpreted and ultimately a decision to continue, develop or terminate the program is made" (Sağlam \& Yüksel, 2007: p. 176). During the program evaluation process, the objectives of the program, the appropriateness of the content to the student level, the correct selection of the teaching methods, techniques and materials, and the extent to which the determined goals are achieved are examined (Saylor \& Alexander, 1974). Program evaluation may result in the decisions about the continuation of the program, review and development of the program, or the termination and replacement with a new program (Ornstein \& Hunkins, 2004).

Knowing the opinions of those who implement the programs in the evaluation of the programs is important for the implementation of the programs as planned. Obtaining the views of faculty members as practitioners is important in terms of the acceptance of the programs and their implementation and success as planned. In the introductory document, the statement of the chairman of the HEC "I hope that these opinions of ours as HEC will be carried to and implemented in classroom environments by faculty members taking an active role in the training of teachers and by teachers who will provide guidance in our schools" explicitly pinpoints the key role taken by faculty members.

It is thought to be useful to evaluate the programs that were put into effect in the 2018-2019 academic year on the basis of the perspectives and experiences of faculty members. It is foreseen that the results will be useful in the renewal of the programs in the future. Therefore, the current study aimed to evaluate the 2018 initial teacher training programs. To this end, answers to the following questions were sought. 
Özgür Ulubey, Semra Başaran - Uluslararası Eğitim Programları ve Öğretim Çalışmaları Dergisi, 9(2), 2019, 263-300

1. What are the faculty members' opinions about the development process of the 2018 initial teacher training programs?

2. What are the faculty members' opinions about the changes made in the 2018 initial teacher training programs?

3. What are the faculty members' opinions about the contribution of the 2018 initial teacher training programs to the quality teacher training?

4. What are the faculty members' opinions about the teaching practices opportunities in the 2018 initial teacher training programs?

\section{Method}

\section{Research Design}

The basic interpretive qualitative research design (Merriam, 2013) was used in this study. In this design, it is attempted to make sense of the experiences of the participants, their perceptions of the subject or process being investigated and their experiences while interacting with the world. In other words, the meanings and reflections created by the participants about the research process are taken into consideration. The aim of the research process in the basic interpretive design is to determine how the participant, who is the data source, makes sense of a situation or event (Altheide \& Johnson, 2011). In the current study, the basic interpretive qualitative research design was preferred as it was aimed to evaluate the renewed initial teacher training programs put into effect in the 2018-2019 academic year in education faculties on the basis of the perspectives and experiences of the faculty members. To this end, in line with their experiences about the initial teacher training programs in-depth examination of the faculty members' opinions about the 2018 initial teacher training programs and a detailed description of the meanings and interpretations they developed in this context were made.

\section{Study Group}

The study group of the current research is comprised of faculty members working in the Education Faculty of a university located in the western part of Turkey. Participants of the study are 32 faculty members who are working in the science, pre-school, elementary school, special education, computer and instructional technology, mathematics, Turkish, social studies, music, art, English, German initial teacher training programs, guidance and counseling, educational management and curriculum and instruction programs and participating in the current study on a volunteer basis. In the selection of the faculty members, maximum variation sampling, one of the purposive sampling methods, was used. Great care was taken to include faculty members from different professional seniorities ( 3 to 25 years) and with different academic titles from each department. As a result, the study group, 18 of which were males, consisted of 12 doctor instructors, 10 associate professors.

\section{Data Collection Method and Tool}

In order to determine the opinions of the faculty members a semi-structured interview form was developed. The interview items were prepared in such a way as to determine the faculty members' opinions about the updated programs, what these programs mean to them and to collect in-depth information about the new programs on the basis of their experiences and to make sense of this information. For the purposes of the current study, an item pool was generated and the interview form was formed by selecting items from this pool. Expert opinions were sought about the form and then it was revised on the basis of the feedbacks from the experts. The interview form was piloted on three faculty members. After this piloting, its final form was given to the data collection instrument. In the final version of the interview form, there are five items. Two of these items are given as samples below: "What are your opinions about the development process of the 2018 initial teacher training programs?" and "What are your opinions about the changes made in the 2018 initial teacher training programs?" 


\section{Data Collection Process}

In order to collect the data, first, permission was obtained from the dean of the faculty where the research would be conducted, then, the interview process was started. The researchers gave information about the purpose and scope of the research to the faculty members who were planned to be interviewed. They were asked whether they were voluntary for the study. With the faculty members who had accepted to participate in interviews, date and time for the interview were set. Then, interviews were conducted with the faculty members. Before the interviews, permission of the participants was taken for tape-recording. The interviews were conducted in the faculty members' own offices so that they could feel comfortable and each interview lasted for 20-30 minutes. The interviews were tape recorded. After giving a code each audio recording was transcribed into written documents. Audio Recordings and their written forms are kept in a file in a computer requiring a password to enter.

\section{Data Analysis}

The interview recordings were analyzed by strictly adhering to the participants' opinions. The data were analyzed by using the inductive content analysis. Written documents read few times and coded in two cycles. In the first cycle, open and in-vivo coding was performed on the data and axis coding was performed in the second cycle. Then, the relationships between the codes under the themes identified were explained and interpreted, and direct quotations were used to analyze the cause and effect relationships.

\section{Validity and Reliability Studies}

The strategies of expert review, detailed description, and formation of a study group and confirmation of the results were used to strengthen the credibility, transferability, confirmability and consistency of the current research (LeCompte \& Goetz, 1982; Linkoln \& Guba, 1985; Patton, 2014; Tedlie \& Tashakkori, 2009). Within the context of the current study, a meeting was held with a researcher specialized in qualitative research methods and information was given about the research process. The results of the research were shared with this particular expert and the validity of the approaches and thinking styles of the researchers were evaluated together with him. Detailed description was used to ensure the transferability of the research (Lincoln \& Guba, 1985; Meriam, 2013; Teddlie \& Tashakkori, 2009; Yıldırım \& Şimşek, 2013). The participant selection process and the characteristics of the participants, data collection and analysis processes and the role of the researcher were explained in detail under the title of method; thus, transferability was ensured. In addition, in order to ensure variety in the selection of individuals to be interviewed, faculty members with different seniorities and titles were selected from each department. Moreover, the findings of the research were presented without comment and themes were supported with direct quotations. In the data analysis process, assistance was also received from another qualitative research specialist and the results were confirmed to ensure consistency. In this context, the expert was asked to comment on the relevance of the themes and sub-themes created for each data text. A consensus was reached by discussing the themes and codes on which there had been disagreement.

\section{Role of the Researcher}

The researchers carrying out the study have been working as faculty members in the education faculty for a long time. Both researchers have studies on teacher education and qualitative research. Therefore, it can be said that they are experienced in the research subject and qualitative research. After the teacher training programs were updated and this was announced to education faculties, preparations of the current study were started. First, the framework of the study was determined, then the related literature was reviewed and the data collection tool was developed. The process from the preparation of interview items to the reporting of the research was carried out by the researchers who are experts in qualitative research. 


\section{Results}

In the current research evaluating the 2018 initial teacher training programs, the findings were gathered under the following headings: the faculty members' opinions about the development of the initial teacher training programs; their opinions about the contributions of these programs to the quality teacher training; their opinions about the innovations brought about by them and their opinions about the teaching practices in these programs. The details of the opinions are given below in tables. The faculty members' opinions about the development of the initial teacher training programs are given in Table 1.

\section{Table 1}

Opinions about the Development of the 2018 Initial Teacher Training Programs

\begin{tabular}{|c|c|}
\hline Themes/Codes & f \\
\hline Opinions about the Development of the Programs & 75 \\
\hline General Opinions about the Program Development Process & 14 \\
\hline The programs were not prepared in exact compliance with the program development & 4 \\
\hline process & 4 \\
\hline The programs were not developed in line with the requirements of the program & 3 \\
\hline development process & 3 \\
\hline \multirow{2}{*}{\multicolumn{2}{|c|}{$\begin{array}{l}\text { The program development works were not systematically conducted } \\
\text { A centralized program development process was followed }\end{array}$}} \\
\hline & \\
\hline Opinions about the Commissions in the Program Development Process & 31 \\
\hline Invitations to the commissions were not transparent & 7 \\
\hline Decisions made in the commissions were not reflected in the programs & 6 \\
\hline Some commission members were not invited to the symposium & 5 \\
\hline Decisions made in the commissions were changed in the symposium & 4 \\
\hline $\begin{array}{l}\text { Some decisions made by the commissions were not supported by the majority of the } \\
\text { commission members }\end{array}$ & 3 \\
\hline Opinions of educational scientists were not much taken into consideration in the & 3 \\
\hline commissions & 1 \\
\hline The number of subject-area educators was high & 1 \\
\hline The opinions of subject area educators were dominant & 1 \\
\hline \multicolumn{2}{|l|}{ Subject area educators were resistant to change } \\
\hline Opinions about HEC in the Program Development Process & 24 \\
\hline Academic autonomy is not granted to education faculties & 7 \\
\hline The main focus is training of prototype teachers & 5 \\
\hline The main focus is on centralized teacher training & 4 \\
\hline Contents found to be suitable by HEC are imposed & 3 \\
\hline HEC does not seek for the detailed opinions of stakeholders & 2 \\
\hline The opinions of stakeholders do not find reflections in the programs & 1 \\
\hline Not enough consideration is given to main schools of teacher training & 1 \\
\hline Centralized program development process is not functional & 1 \\
\hline Suggestions about Program Preparation Process & 6 \\
\hline Draft programs should be prepared at universities & 1 \\
\hline Education faculties should be allowed to make their own changes & 1 \\
\hline Opinions of stakeholders should be sought in a more comprehensive manner & 1 \\
\hline Programs should be evaluated through pilot applications & 1 \\
\hline Data should be provided for the program development process by detecting the deficiencies & 1 \\
\hline in the programs & 1 \\
\hline $\begin{array}{l}\text { There should be program development experts recruited at universities and they should } \\
\text { check the application of the programs }\end{array}$ & \\
\hline
\end{tabular}

In Table 1, the faculty members' opinions on the preparation of the 2018 initial teacher training programs are presented. These opinions are accumulated under the themes of; the program development process, commissions in the program development process, HEC and suggestions for the program development process. 
It was seen that the opinions of the faculty members about the preparation process of the teacher training undergraduate programs were negative in general. The faculty members stated that the programs were not prepared according to the program development process $(f=4)$ and its requirements $(f=4)$. They criticized the lack of planning in the works done in the program development process $(f=3)$ and centralized development of the programs $(f=3)$. Some related quotations are given below.

K8: The understanding of program development has not been internalized in our country. If the programs had been prepared in compliance with the real program development process, the problems experienced at schools (in the programs) could have been revealed better.

K11: HEC centrally updated the undergraduate programs yet what did we do for two months? We wrote contents for the courses they imposed on us.

K9: If the opinions were really taken into account ... Opinions may be elicited just to find justification to the centrally imposed ideas; thus, our opinions do not find reflections in the programs. I had been asked for my opinions about the former programs, and they were not very influential on the programs.

K2: There are few prominent figures in the field. None of them leading the field were involved in the program development process.

The faculty members who took part in different program commissions stated that their opinions were not taken into consideration sufficiently. The faculty members stated that there was no transparency in the invitations to the program commissions $(f=7)$, the decisions taken in the commission were not reflected in the programs ( $f=6)$, some commission members were not invited to some subsequent meetings $(f=5)$ and some of the decisions taken at the commissions were changed in the symposium $(f=4)$. In addition, they stated that some decisions taken in the commissions were not by the majority vote $(f=3)$ and the opinions of education scientists were not taken into consideration $(f=3)$. The reason for this according to them was the high number of subject area educators in the commissions, their dominance on the programs and their being resistant to change. Some related quotations are given below.

K9: In a symposium held in Eskişehir, some reaction came from somewhere or something happened in HEC. A change was made on that program. Different results from the ones we though in the first commission came out.

K8: What emerged at the end was different from what had been discussed in the commissions; the views expressed in the commissions were not reflected in the programs. It is not certain which criteria were used to invite the people into these commissions.

K11: Usually the things defended by the majority were taken into consideration; my personal opinions were a bit overlooked.

K5: We expressed our opinions about some courses. No change was made in relation to these courses.

K11: It was very clear that they (subject area educators) did not want to listen to. According to them, what is important is the inclusion of an adequate number of content knowledge courses in the programs; pedagogical content courses and educational sciences courses are not very important. Therefore, I do not think that my views were taken into consideration.

The faculty members levelled criticisms against the preparation of the programs by HEC. In this connection, they stated that as the programs were centrally developed, not much autonomy was granted to education faculties $(f=7)$, which led to training of prototype teachers $(f=5)$ and that too much emphasis was put on centralized training of teachers $(\mathrm{f}=4)$. They also stated that the contents of the programs were prepared as stipulated by HEC $(f=3)$, that the opinions of stakeholders were not much sought $(f=2)$, that few opinions received from stakeholders were reflected in the programs $(f=1)$ and that this led to ignorance of the successful teacher training approaches $(f=1)$ and that autonomy in teacher training was not achieved. They also emphasized that programs developed in this way would not be functional $(f=1)$. Some relevant quotations are given below.

K7: Prototype ... what I mean in a single framework. This does not work of course, expectations in each discipline are different; they have different teacher profiles so if you try to train prototype teachers; can this be a solution as each discipline has different requirements? Of course not ... 
K11: The teacher training undergraduate programs were centrally changed by HEC. In the first meeting, I was able to express my opinions at least; yet, in the second meeting, I wasn't even informed about it

K17: The general framework of the programs was enforced by the central authority, which decreased the functionality. If the revisions were made taking the local opinions much into consideration, then the programs would be much more functional and effective in terms of meeting the needs of students.

The faculty members made suggestions for solving the problems in the program preparation process. In this regard, they suggested that draft programs should be prepared at universities $(f=1)$, that education faculties should be allowed to make their own changes $(f=1)$, that opinions of stakeholders should be sought in a more comprehensive manner $(f=1)$, that programs should be evaluated through pilot studies $(f=1)$, that data should be provided for the program development process by detecting the deficiencies in the programs $(f=1)$, that there should be program development experts recruited at universities and they should check the implementation of the programs $(f=1)$. In this regard, some related quotations are given below.

K8: Rather than centralized attempts, at schools for example at universities draft programs should be developed at departments and then these draft programs should be sent to universities and then be discussed in meetings including concerned officials from HEC.

K25: Opinions should be certainly sought and the process should proceed from bottom to top.

K16: First, deficiencies should be determined by taking the evaluations of universities about the program. In light of the opinions expressed by universities, problems should be discussed and then more comprehensive discussions should be conducted in congresses. Results of scientific research, opinions of students and teachers should be used to shape the program development process, which would be healthier. We immediately implement the program, and then we do not evaluate it for years. We can only evaluate it 10-20 years later. On the contrary, whenever we see a shortcoming in the program, we should look for ways of correcting it.

The faculty members' opinions about the changes made in the 2018 initial teacher training programs are given in Table 2.

The opinions of the faculty members about changes made in the 2018 initial teacher training programs are related to the content, elective courses and harmony between content knowledge, pedagogical content knowledge and general culture courses. The faculty members levelled criticisms against the reduction of class periods in the programs $(f=20)$, lack of balance between the time periods allocated to theoretical classes and practice classes $(f=16)$, the high number of courses $(f=15)$, keeping the content the same in general $(f=14)$, overlapping contents of some courses $(f=9)$ and restriction put on the proposing a different elective course $(f=1)$. On the other hand, they considered the addition of educational sociology and philosophy of education into the programs as must courses $(f=1)$ is positive development. Some related quotations are given below.

K11: In the first class period, you can deliver the lesson just for 10 or 15 minutes. In the second class period, the students enter the class and then the lesson is wrapped up and then the class is over, nothing efficient can be done ... when the course used to be four class hours a week in the past, it was more efficient as we could spend some time doing practice; students used to enjoy it more.

K2: The class periods were not reduced in our course, remaining three class hours a week. What we expected was an increase in the class hours of this course.

K10: In my department, it is very difficult to cover the content. For some courses, decreasing the number of class hours is good while for some others, it is not good. For instance, the class hours of the course I am teaching were reduced from three class hours to two class hours a week; it is not possible to cover the content. Contents of most courses overlap ...

K22: In some departments, there is no problem but in our department, course load is too intense.

K2: Teaching inclusive classes was a required course. This course is not required any more. This might have been decided by the MoNE or HEC but $30 \%$ of the classes in Turkey are inclusive classes ... 30 out of 100 classes are inclusive classes...

K4: Addition of the educational sociology and philosophy of education courses into the programs is good. Students need to learn these. They need to learn the theory, foundation and social content well. 
Table 2

Opinions about the Changes Made in the Initial Teacher Training Programs

\begin{tabular}{|c|c|}
\hline Themes/Codes & f \\
\hline General Opinions about the Content & 75 \\
\hline Class periods have been decreased & 20 \\
\hline There is a lack of balance between the time periods allocated to theoretical classes and & 16 \\
\hline practices & 15 \\
\hline The number of courses is high & 14 \\
\hline Course contents have remained the same in general & 9 \\
\hline Contents of some courses are overlapping & 1 \\
\hline Addition of education sociology and education philosophy courses has been found to be & 35 \\
\hline useful & 17 \\
\hline Opinions about Elective Courses & 10 \\
\hline \multicolumn{2}{|l|}{ Positive Opinions about Elective Courses } \\
\hline The number of elective courses has been increased & 7 \\
\hline The high number of elective courses indicates the existence of more autonomy- & 17 \\
\hline oriented approach & 5 \\
\hline Negative Opinions about Elective Courses & 4 \\
\hline The number of instructors is not enough for elective courses & 3 \\
\hline HEC approval for opening elective courses is restrictive & 2 \\
\hline Deciding which field experts will give elective courses is problematic & 1 \\
\hline There are applications not consistent with the reality & 1 \\
\hline The possibility of offering a different elective course is limited & 1 \\
\hline \multicolumn{2}{|l|}{ The amount of practice in courses has been decreased } \\
\hline \multicolumn{2}{|l|}{ Only the names of some courses have been changed } \\
\hline Harmony between Content Knowledge, Pedagogical Content Knowledge and Culture Courses & 39 \\
\hline Opinions about Content Knowledge Courses & 16 \\
\hline Number of content knowledge courses is high (According to educational scientists) & 6 \\
\hline Basic content knowledge courses have been removed & 5 \\
\hline HEC approval is needed for opening a new elective content knowledge course & 4 \\
\hline Content knowledge courses are not determined according to needs & 1 \\
\hline Opinions about Pedagogical Content Knowledge Courses & 17 \\
\hline Class periods allocated to pedagogical content knowledge courses have been reduced & 7 \\
\hline $\begin{array}{l}\text { Pedagogical content knowledge courses are too many (According to subject area } \\
\text { educators) }\end{array}$ & 5 \\
\hline $\begin{array}{l}\text { HEC approval is needed for opening a new elective pedagogical content knowledge } \\
\text { course }\end{array}$ & 5 \\
\hline Content Knowledge, Pedagogical Content Knowledge and General Culture Courses are & 5 \\
\hline Balanced & 1 \\
\hline \multicolumn{2}{|l|}{ Decreasing the Number of General Culture Courses } \\
\hline Suggestions toward the Content & 33 \\
\hline Contents should be determined according to students' needs & 7 \\
\hline There should not be required elective courses & 5 \\
\hline Laboratory courses should be opened again & 4 \\
\hline Practice periods should be added to theoretical class periods & 4 \\
\hline There should be courses that can be adapted to any given subject area & 3 \\
\hline Courses should be practice-oriented & 3 \\
\hline The number of content knowledge courses should be increased & 2 \\
\hline Courses specially tailored for the qualifications of a faulty member should not be opened & 2 \\
\hline The characteristics of the region where the faculty is located should be taken into & 1 \\
\hline consideration & 1 \\
\hline Students should be able to select courses according to their needs & 1 \\
\hline Courses should be instructed by the instructors specialized on their contents & \\
\hline
\end{tabular}

The faculty members evaluated the increase in the number of elective courses in the programs $(f=10)$ and the high number of elective courses as an indication of a more-autonomy-oriented approach $(f=7)$. However, they see the lack of faculty members for elective courses $(f=5)$ and the approval of HEC for adding elective 
pedagogical content knowledge courses $(f=4)$ as a limiting approach. They expressed negative opinions about the uncertainty of which field experts will teach some elective courses $(f=3)$, the decrease in the amount of practice in the programs $(f=1)$ and only changing the names of some courses $(f=1)$. Some related quotations are given below.

K18: Offering elective courses to students each term and students' being able to take the courses they like seemed to be an indication of a liberating approach initially but then during the development process it has been turned to highly restrictive.

K6: Elective courses are a little more liberating, we can open courses at any time, but I would like it to be more liberating in terms of being able to open the courses we want.

K7: The number of elective courses has been increased a lot. Different viewpoints, enrichment; thus, seems to be more functional for directing students.

K1: The low number of experts in each field, or the low level of proficiency of teachers who do not have much experience in the related field may of course lead to the problem that irrelevant courses can be opened here.

The faculty members expressed their different opinions regarding the content knowledge and pedagogical content knowledge courses. The faculty members working in the field of educational sciences stated that the courses related to the content knowledge were dominant in the programs $(f=6)$. The faculty members working in the field of subject area education stated that they were uncomfortable with the removal of the basic content knowledge courses $(f=5)$. They stated that submission of elective content knowledge courses for the approval of the HEC would be a challenge $(f=4)$. Another criticism in this regard was that content knowledge courses were not determined according to needs $(f=1)$. Some relevant quotations are given below.

K1: The class periods allocated to content knowledge courses such as physics, chemistry, and biology were decreased.

K19: In order to open a course in the field of subject area education, it should be sent to HEC and be approved by it...

K7: On the basis of the decrease in the number of courses, I was expecting that the ratio of our courses would be more but the exact opposite occurred in reality and the number of pedagogical content knowledge courses decreased.

The faculty members who teach pedagogical content knowledge courses stated that they found the removal or reduction of the amount of practice in the pedagogical content knowledge courses as a negative development $(f=7)$. The faculty members teaching content knowledge courses stated that pedagogical content knowledge courses were dominant $(f=5)$. The faculty members think that the submission of elective pedagogical content knowledge courses to the approval of HEC may lead some problems $(f=5)$. In addition, there are faculty members stating that there is a balance in the distribution of pedagogical content knowledge, content knowledge and general culture courses $(f=5)$ and that general culture courses should be reduced $(f=1)$. Some related quotations are given below.

K2: Pedagogical content knowledge and content knowledge courses were set to be required courses by HEC. Thus, it is a must to open these courses. HEC also says "if you offer another course apart from these, then you need our approval." This is a very long process ... In the past, with the approval of the senate, we were able to open that course.

K6: We had a drama course. Two class hours used to be allocated to theory and the other two class hours to practice. Now it is only two class hours to teach just theory...

K21: As stated in the books we read, there should be $50 \%$ content knowledge courses, $25 \%$ general culture courses, $25 \%$ pedagogical knowledge courses.... it was emphasized that this was ideal for the training of good classroom teachers. But now these ratios are very close to each other...

K8: The number of general culture courses was decreased a bit. I think each teacher should have general culture. A teacher who does not enough general culture cannot be successful. 
The faculty members made some suggestions about the programs. They believed that the contents should be determined to fulfil the students' needs $(f=7)$, there should not be "must elective" courses in the programs $(f=5)$, laboratory courses should be opened again $(f=4)$, practice periods should be added to theoretical class periods $(f=4)$, there should be courses that can be adapted to any given subject area $(f=3)$, courses should be practice-oriented, the number of content knowledge courses should be increased $(f=2)$, courses specially tailored for the qualifications of a faulty member should not be opened $(f=2)$, the characteristics of the region where the faculty is located should be taken into consideration $(f=1)$, students should be able to select courses according to their needs $(f=1)$, courses should be instructed by the instructors specialized on their contents $(f=1)$. Some related quotations are given below.

K8: What is the need of teachers for future? Is this need adequately met? If not, what is the problem? The issue should be seen from this perspective.

K32: Elective courses are offered to reflect the richness of the instructor but we have required elective courses.

K29: The most problematic part of the programs is the decreased practice opportunities I think that greater emphasis put on theory than practice in the programs is a negative development.

K1: Class periods of the content knowledge courses such as physics, chemistry and biology should be increased and new courses should be opened in this regard ...

K17: They can be more effective while developing these programs. Curriculum development experts from different regions may be involved so that better programs more suitable for regional needs can be created. Programs may differ from region to region taking regional needs into consideration.

The faculty members' opinions about the contribution of the teacher training programs to the quality teacher education are given in Table 3.

\section{Table 3}

Opinions about the Contribution of the Teacher Training Programs to the Quality Teacher Training

\begin{tabular}{lc}
\hline Themes/Codes & $\mathbf{f}$ \\
\hline The Programs' not Contributing to the Training of Qualified Teachers & $\mathbf{4 2}$ \\
Decreasing number of class hours & 12 \\
Abolishment or reduction of the time allocated to practice in courses & 9 \\
Increase only in the number of theoretical class hours & 7 \\
Removal of the school experience course & 7 \\
Development of the programs without considering the needs of the field & 5 \\
Not increasing the time allocated to teaching practice & 2 \\
Suggestions about Qualified Teacher Training Programs & $\mathbf{4 3}$ \\
The amount of time allocated to teaching practice should be increased & 7 \\
Needs analysis should be conducted while revising the programs & 6 \\
Research findings should be taken into consideration while revising the programs & 5 \\
Program evaluation works should be conducted & 4 \\
Faculty members who will implement the programs should be qualified & 4 \\
Practice schools should be opened & 4 \\
Education faculties should be opened in central locations & 3 \\
Programs should be oriented to the training of intellectual teachers & 3 \\
The number of students in classes of education faculties should be decreased & 3 \\
Physical conditions should be improved & 2 \\
There should be adequate tools and equipments & 1 \\
There should be environments supportive to pre-service teachers' social, cultural & 1
\end{tabular}

As can be seen in Table 3, some faculty members think that the teacher training undergraduate programs would not contribute to the training of qualified teachers. The reasons proposed by them to support their opinions include decreasing number of class hours $(f=12)$, abolishment or reduction of the time allocated to practice in courses $(f=9)$, increase only in the number of theoretical class hours $(f=7)$, removal of the school 
experience course $(f=7)$, development of the programs without considering the needs of the field $(f=6)$, not increasing the time allocated to teaching practice $(f=2)$. Some related quotations are given below.

K8: Rather than training qualified teachers ... Because of the reasons I have just mentioned ... First the number of class hours was decreased especially the ones allocated to practice; training would be more theory-oriented. Another important thing is that the profession of teaching is learned by doing; thus, if you decrease their opportunity of doing practice and interacting with schools, then you will negatively affect the quality in teacher training. It dropped to $7 \%$ here. It is not a program which is an outcome of comprehensive thinking, scientific research and consideration of the needs of the field, which will decrease the quality.

The faculty members made some suggestions about the 2018 initial teacher training programs so that more qualified teachers could be trained. According to the faculty members; the amount of time allocated to teaching practice should be increased $(f=7)$, needs analysis should be conducted while revising the programs $(f=6)$, research findings should be taken into consideration while revising the programs $(f=5)$, program evaluation works should be conducted $(f=4)$, faculty members who will implement the programs should be qualified $(f=4)$, practice schools should be opened $(f=4)$, education faculties should be opened in central locations ( $f=3)$, programs should be oriented to the training of intellectual teachers $(f=3)$, the number of students in classes of education faculties should be decreased $(f=3)$, physical conditions should be improved $(f=2)$ and there should be adequate tools and equipments to train qualified teachers $(f=1)$. Moreover, there should be environments supportive to pre-service teachers' social and cultural development $(f=1)$. Some related quotations are given below.

K4: I am very sincere that the teaching practice should be given each term because real school and classroom environments are very different; you learn everything by practicing.

K8: The number of students in classes should be decreased. Physical conditions should be improved. It is not possible to practice in classes having 80 students. Teaching materials in the class should be adequate and quality. You see, there are smart boards in many schools. However, there are no smart boards in education faculties. There is not enough equipment in laboratories. There are no environments where students can freely express and discuss their opinions and can participate in social and cultural activities. The more qualified a teacher is, the better it is ... There should be practice schools. It is not good to open education faculties everywhere; they should be established in central locations so that students can go to opera, theatre, take part in artistic activities, social activities. First of all, the program must be good. But the program is not enough on its own. Faculty members must be qualified as well. In which courses are they happy, which courses are more efficient, which courses are inefficient and why? Teachers say that these courses do not make much contribution to the field, why? Faculty members do not teach their classes effectively, just lecturing, no practice in the class. If research findings are taken into consideration, problems can be seen; which courses are needed? What problems are experienced by students? If we increase practice more, then we will be more successful.

Faculty members' opinions about teaching practices are given in Table 4. The faculty members' opinions about the teaching practice and school experience courses are presented in Table 4 . The faculty members stated that the time allocated to teaching practice course was not enough $(f=9)$, that they couldn't focus on teaching practice due to their heavy workload $(f=6)$, that they did not go to school to make observations $(f=3)$, that they did not want to give teaching practice course in these conditions $(f=3)$ and that faculty members were distanced from teaching practice course $(f=2)$. Some related quotations are given below.

K7: A faculty member has classes to teach, needs to do some research and at the same time has some students that need to be monitored in their teaching practice classes. When I try to spare time to all of these, it would not be possible to do all as they should be done ideally... Given that my workload is very high, this does not work.

K8: As many instructors do not go to schools, they cannot observe many teaching practice classes. This is negative. In my opinion, it is possible to go there four times, this is manageable. Yet, the instructor has a problem; he/she has many courses to teach and they are different courses. When we think that he/she goes to observe eight students four times for each, then he/she needs to go 32 times. 
Table 4

Opinions about Teaching Practices

\begin{tabular}{lc}
\hline Themes/Codes & $\mathbf{f}$ \\
\hline Opinions about Teaching Practice & $\mathbf{2 3}$ \\
Not enough time is allocated to teaching practices & 9 \\
High workload of faculty members & 6 \\
Inability of making observations at schools due to workload of faculty members & 3 \\
Faculty members' not wanting the teaching practice course due to their workload & 3 \\
Long-time of practices make faculty members reluctant to take responsibility & 2 \\
Opinions about the Teaching Practice Course & $\mathbf{1 6}$ \\
Exclusion of the school experience course from the 2018 programs & 8 \\
Getting to know the profession & 4 \\
Preparation for the profession & 4 \\
Suggestions about Teaching Practice & $\mathbf{3 2}$ \\
Teaching practice should be started at earlier periods of the initial program & 10 \\
The time allocated to teaching practice should be increased & 9 \\
Initial teacher training programs should be organized to be theoretical for three & 3 \\
years and practical for one year & 3 \\
Faculty members should be paid for teaching practice classes & 3 \\
The workload of faculty members should be decreased & 3 \\
What is learned at faculties should be practiced at schools & 1 \\
Teaching practice should be taken more seriously &
\end{tabular}

The faculty members also stated their opinions about the school experience course. The faculty members criticized the exclusion of the school experience courses from the 2018 initial teacher training programs $(f=8)$; they thought that the school experience course is important in terms of getting to know the profession of teaching $(f=4)$ and for preparation for the profession $(f=4)$; thus, it should not have been excluded from the programs. Some related quotations are given below.

K10: Given the experiences lived by students in the school experience and teaching practice courses, the teaching practice course should be started in the first year of the undergraduate program.

K6: I am pondering about two things; I was expecting the school experience course would be started in the second term of the first year of the undergraduate education; instead, it was completely excluded from the programs. It is something like telling a science teacher to start teaching science without having any laboratory experience.

K21: If the school experience course were started in the first year, and then slow transition from observations to practices in the class were realized, students could get to know the teaching profession better and feel more prepared for the profession or decide whether the teaching profession would be suitable for them or not.

The faculty members made suggestions for high quality teaching practices. They believed that teaching practice should start at earlier periods of the initial teacher training programs $(f=10)$, the time allocated to teaching practice should be increased $(f=9)$, initial teacher training programs should be organized to be theoretical for three years and practical for one year $(f=3)$, faculty members should be paid for teaching practice classes $(f=3)$, the workload of faculty members should be decreased $(f=3)$, what is learned at faculties should be practiced at schools $(f=3)$ and teaching practice should be taken more seriously $(f=1)$. Some related quotations are given below.

K7: I want the teaching practice course to be started in the spring term of the first year; students to go to school for observations, then I want such a course to be offered to students each term so that students can see and experience the real school and classroom environment and atmosphere.

K2: I think; it would be better for students to go to school every day. There should be coordinators of faculties to organize this. The only duty of this coordinator should be to control the process by visiting the schools where students are doing their teaching practice. Even each department or program can have a coordinator to do this. This would be healthier. 
K27: How should teaching practice be? In my opinion, at the end of the third year, theoretical courses should be ended. The last year should be allocated to practice. Students can spend the whole year at schools doing practice.

K5: Schools should be turned into laboratories which should be visited continuously.

K8: Teaching practice should be taken more seriously.

\section{Discussion, Conclusion and Implications}

In the current study, aiming to evaluate the 2018 initial teacher training programs, the results were obtained regarding the opinions of the faculty members on the development of the 2018 initial teacher training programs, changes made in the programs, their contribution to the training of qualified teachers, the school practices and their suggestions for the programs. In this section, these results are further elaborated.

Since the development of training programs is a comprehensive and continuous work, the need for carrying it out through commissions is emphasized. These commissions may consist of three groups: program decision and coordination group, working group and advisory group. Faculty members in the program working groups should be field experts (Demirel, 2015; Ornstein \& Hunkins, 2014). For these groups to work effectively, selection process of these experts must be merit-based and transparent. The views of the selected experts should be given importance and reflected in the programs. The faculty members questioning the merits and way of the selection of the experts invited to the 2018 initial teacher training programs development commissions formed the basis of this recommendation. It was seen that the necessary explanations were not made in the introduction sections of the programs. Absence of the necessary explanations about the program development commissions has caused faculty members to develop a negative perspective on initial teacher training programs. This could have made it difficult for faculty members to accept and implement the programs. In addition to the problems that arose during the commissioner's selection process, the selected commissioners also experienced problems. The faculty members in the commissions stated that the proposals they made during the program development process were not taken into consideration, decisions were not taken by majority and that these decisions were changed without informing the concerned individuals. Moreover, majority of the members in the commissions were subject area specialists. This might have resulted in the dominance of subject area specialists in the decisions related to the development of the programs. As the decisions were not taken by majority opinion, the suitability of the programs for quality teacher training becomes disputable.

The faculty members stated that programs should be evaluated before they are developed. In the program evaluation process, questions such as whether the objectives, content, instructional methods and materials of the program are age-level appropriate and reachable are tried to be answered (Saylor \& Alexander, 1974). As a result of this evaluation, decisions about the continuation, termination, or reconstruction of the program (Ornstein \& Hunkins, 2004) could be possible. In order to prepare new programs, it is necessary to evaluate the previously prepared programs and identify the deficiencies in these programs (Demirel, 2018; Ornstein \& Hunkins, 2004). However, when the reasons for replacing the former teacher training programs with the new programs and the opinions of the faculty members about the program development process are examined, it is understood that new programs are prepared without program evaluation studies. In the explanations about the programs, it was stated that the results of the scientific studies and symposiums, panels, workshops, open sessions, conferences organized by the MoNE and non-governmental organizations were taken into consideration during the process of updating the programs. It was stated that the programs were renewed for reasons such as adaptation to the changes made in primary education programs and making the programs suitable for European Higher Education Area (HEC, 2018). In order for the programs to be renewed, they must be thoroughly evaluated and then updated considering the evaluation results. When the explanations made by HEC (2018) about the initial teacher training programs are examined, it is seen that the without any nationwide study, the results of small-scale studies were taken into consideration. Though it is the first year of implementation of the initial teacher training programs MoNe (2018a) was pointed out that they will be revised (MoNe, 2018a). Stating that the programs could be changed again in the first year of their implementation clearly shows the problem of coordination and sustainability in teacher training policies.

As institutions of higher education, universities are autonomous and universal. Universities must have financial, academic and administrative autonomy. Financial autonomy refers to the management of resources and expenditures of a university by itself (Erdem, 2013). Administrative autonomy refers to the governance and 
supervision of the university and safeguarding of rights of its personnel by bodies democratically established by its own members (Aktan, 2008). Finally, academic autonomy refers to the ability of the university to select the research and development areas, the education programs and the course contents, and the scientists (faculty members) by itself, in short, the institution itself can decide what to teach and what to research and by whom (Estermann, Nokkola \& Steinel, 2011). One of the most important elements of academic autonomy is the ability of universities to determine their own curricula and course contents. Although the faculties of science, literature, economics and engineering within the same university can form their own programs, faculties of education cannot prepare programs specific to their unique structure. Centrally prepared programs by HEC are implemented in education faculties. Some faculty members criticize this situation and find it against academic autonomy. The central development of the programs poses an obstacle against the development of unique approaches to teacher training and the introduction of creative and original models in teacher training. Thus, it can be said that this situation is not suitable for the academic autonomy of education faculties and that HEC can form a general framework.

It is understood that the opinions about the changes made in the initial teacher training programs are also negative in general. The faculty members stated that they did not find it right to decrease class periods of the courses. They stated that it would be harder to achieve the objectives of the courses when the class periods allocated to the courses were reduced.

The philosophy of education is seen as an effort to determine the things education should do. The philosophy of education tries to explain the problems of education and the concepts and ideas that direct education (Ergün, 2015; Sönmez, 2017). As such, teachers need to think about education and wonder about reality, human nature and society (Gutek, 2016). In order for teachers to mentally question and to make philosophy, there must be a course such as philosophy of education.in initial teacher training programs. The philosophy of education course can be helpful for pre-service teachers to do their profession better by gaining a philosophical perspective towards education (Aslan, 2014). For this reason, it has been stated in the studies that the philosophy of education course should be included in all departments of the faculties of education (Duman \& Ulubey, 2008). In the 2018 initial teacher training programs, the required philosophy of education and educational sociology courses were included. The faculty members considered the incorporation of these courses into the programs as a positive development. These courses are important for pre-service teachers to gain philosophical and cultural perspectives (Eskicumalı, 2001). Educational sociology is an important course that will enable pre-service teachers to solve problems that they may encounter in different social structures and cultures or subcultures, to act consciously in solving problems and to understand different relationships in a social structure (Tezcan, 2016). Therefore, the pre-service teachers who actively participated in these courses and internalized their contents would be expected to solve the problems confronted in their profession easily and to meet the requirements of their profession better. However, taking the courses of educational sociology and philosophy of education does not guarantee the acquisition of these features. For this reason, relating theoretical knowledge to real life in these courses could make the lessons much more useful.

While the faculty members consider the increase in the number of elective courses as a liberating approach, they think that the number of instructors to teach these elective courses is not adequate. The inadequate number of instructors may lead to the conversion of elective courses into required elective courses. This may make it difficult for programs to achieve their goals. Küçükahmet (2007) pointed out this problem in teacher training programs and stated that as a limited number of elective courses could be opened, these courses were turned into "compulsory" electives. A similar situation may arise in the 2018 initial teacher training programs. Moreover, the necessity of HEC approval for the opening of elective content and pedagogical content knowledge courses may cause some problems. In this regard, the faculty members stated that they did not find the obligation of seeking the approval of HEC correct. They noted that they might not propose new courses due to the procedure for proposing new courses, and that they might even try to open some courses as general culture courses with the approval of the university senate. Or faculty members may tend to open only elective courses offered by HEC. This can be said to negatively affect faculty members' proposals for new creative courses.

The faculty members stated that the courses in the programs should be given by the instructors who are specialized in their fields. Küçükahmet (2007) evaluated the undergraduate programs and concluded that the courses in the programs were taught by the instructors who have not qualified enough in their fields. The 
faculty members had the same concern about the programs put into practice in 2018 since the same issues are valid today as well. It is thought that this application should be solved in order to train qualified teachers.

One of the important changes in the 2018 initial teacher training programs is the abolition of the class periods allocated to practice in some courses. For example, while Instructional Technologies and Materials Design course was four class hours, two of which were theoretical and the other two were applied; in the new programs it changed to Instructional Technologies and the class duration was reduced to two hours of theory. The class periods allocated to the Drama course were generally reduced to two class hours from three or four class hours with no time for practice. Laboratory hours were removed from science courses, but it is stated in the explanations about the programs that practices could be conducted within science classes (HEC, 2018). The best way to prepare for the teaching profession is practice. It is thought that abolishing the applied sections of the courses instead of increasing their number would negatively affect the quality of the teachers. Küçükahmet (2007) criticized the reduction of the practices in the pedagogical content knowledge courses in the 2007 initial teacher training programs. However, while the decrease in the number of classes allocated to practices in the 2007 programs was criticized, it is highly alarming that some of these classes were completely abolished in the 2018 initial teacher training programs. This can be seen as an important deficiency in terms of teaching profession and the quality of the teachers. Therefore, the faculty members may think that these teacher training programs would not contribute to the training of qualified teachers.

The faculty members expressed different opinions about the content knowledge and pedagogical content knowledge courses. While the faculty members working in the field of educational sciences stated that the number of the content knowledge courses is high in the programs, the faculty members who teach subjectarea courses stated that the number of pedagogical content knowledge courses is high. It can be said that in the initial teacher training programs put into force in 1997 and 2006, the ratios of the content knowledge, pedagogical content knowledge and culture courses were close to each other. For example, 50\% of the 1997 initial teacher training programs consisted of content knowledge courses, $30 \%$ of pedagogical content knowledge and \%20 of general culture courses (HEC, 1997), while in the 2006 initial teacher training programs, these ratios were as follows: $50-60 \%$ were content knowledge courses, $25-30 \%$ were pedagogical content knowledge courses and $15-20 \%$ were general culture courses (HEC, 2007). In the programs put into effect in $2018,45-50 \%$ of the programs are content knowledge courses, 30-35\% are pedagogical content knowledge courses and $15-20 \%$ are general culture courses (HEC, 2018). When the 1997, 2006 and 2018 programs are examined, it is seen that the ratio of the content knowledge courses occupy about $50 \%$ of the programs, pedagogical content knowledge courses occupy nearly $30 \%$ of the programs and general culture courses occupy approximately $20 \%$. Though not much change has occurred in the weights of the courses, the faculty members could be thinking that the weights of the courses have changed as the number of class periods allocated to some courses decreased and as they think the courses they specialized on are more important.

Pre-service teachers find the opportunity to question themselves professionally and realize their shortcomings through the practices they are engaged in in the school experience and teaching practice courses. These courses are very important as they provide opportunities for pre-service teachers to prepare for the profession and school (Akpınar, Çolak \& Yiğit, 2012; Kavas \& Bugay, 2009). The importance of teaching practices has also been emphasized in the decisions of the National Education Council. For example, at the 18th National Education Council, it was decided that teaching practice should be conducted during an academic year, as in the candidate teacher adaptation process, under the guidance of instructors and teachers (MONE, 2010). Moreover, in the literature, it was emphasized that the teaching practice course should be extended to a longer period and the time allocated to it is insufficient (Aslan \& Sağlam, 2018; Aydın, Selçuk \& Yeşilyurt, 2007; Baskan, Aydın \& Madden, 2006; Güzel, Cerit-Berber \& Oral, 2010; Şimşek, Alkan \& Erdem, 2013). In the current study, similarly the faculty members stated that the teaching practice course should be given for one year or in every term. However, when the 2018 initial teacher training programs are examined, it is clearly seen that previous studies and decisions of the Council were not taken into consideration. In the current study, the faculty members stated that the duration of the teaching practice course should be increased or even that students should spend a whole term participating in practices at school or that there should be a teaching practice course every term.

For the teaching practice course to accomplish its objectives, pre-service teachers should be observed by teachers and faculty members, their shortcomings should be corrected and good practices should be reinforced. Teachers stated that they had problems in making observations because they were attending the 
lesson together with pre-service teachers. On the other hand, the faculty members stated that they had problems in observing due to their workload and the improper planning of other courses. This result is supported by the literature. Çepni, Aydın and Şahin (2015) reported that pre-service teachers could not be observed sufficiently within the context of the teaching practice course as the time of the teaching practice course overlaps with the class periods of other courses. The faculty members also stated that they could not make observations due to the high course load (Aytaçlı, 2012; Kıyıcı \& Horzum, 2015; Kirksekiz, Uysal, İşbulan, Akgün, Kiyici \& Horzum, 2015). Due to the high number of pre-service teachers for whom faculty members are responsible, they cannot fulfil their responsibilities adequately (Aslan \& Sağlam, 2018; ilin, 2014; Topkaya, Tokcan \& Kara, 2012). The faculty members are expected to observe each of the eight students four times which would mean a total of 32 observations (MoNE, 2018b). When the results of the current study and the results of other studies in the literature are considered together with, it is understood that it is difficult for the faculty members to fulfil the requirements of the teaching practice course in the departments where the workload is high. While fees are paid to the mentor teacher and even the school administrators of the school where the teaching practice is conducted, no fees are paid to faculty members, which could cause them to be reluctant to conduct this course.

The school experience course is as important as the teaching practice course since it is the first time that the pre-service teacher meets the profession. The first impressions the pre-service teacher will have in this course shape what kind of teacher he/she will be to a great extent. In a study, it was revealed that the school experience course increased the awareness of pre-service teachers towards the teaching profession and their own fields (Ekinci \& Tican-Başaran, 2015). However, many pre-service teachers see this course and the teaching practice course as easy and unimportant. Therefore, they do not fulfil their responsibilities within the scope of school experience course (Akdemir, 2013). In some cases, mentor teachers and faculty members can give high and standard marks to pre-service teachers regardless of the extent to which they have fulfilled their responsibilities. Another example of lack of attention to this course is the reduction of the weight of the course in program update processes. While in the 1997 teacher training programs, there were the School Experience I and II courses, in the 2007 teacher training programs, the School Experience II course was abolished. Küçükahmet (2007) criticized the abolition of the School Experience II course and stated that this course was seen as an opportunity for students to get to know the school. In the 2018 initial teacher training programs, the school experience course was completely abolished. Thus, pre-service teachers' opportunities to get to know and prepare for the profession were reduced. In the current study, the abolition of the school experience course was criticized during the interviews with the faculty members because in the school experience course, students can decide whether they are suitable for the profession and whether to continue or leave the profession. For this reason, it is thought that it would be very beneficial to start the school experience course in the early years of the undergraduate education, let alone to abolish it.

In the current study, which aimed to evaluate the 2018 initial teacher training programs, the faculty members stated that the programs were not prepared in accordance with the principles of curriculum development. This result represents a negative outlook for a country like Turkey having a fairly well-established curriculum development culture. İnitial teacher training programs are the most important tools for training qualified teachers. If these tools are prepared with the right curriculum development process, it will be easier and shorter for the country to achieve its long-term goals in a more desirable manner.

Development of the 2018 initial teacher training programs centrally, lack of full reflection of stakeholders' views on the programs, lack of transparency in the assignment of faculty members to work in the commissions formed during the program development process, and lack of systematic curriculum development approach were criticized. Taking these criticisms into consideration, the opinions of all stakeholders from the lowest to the highest level should be taken into consideration when developing the next teacher training programs. Majority opinion should be dominant in the decisions taken in the commissions. The role of HEC in the curriculum development process should be reduced and the academic expertise of faculty members working in the faculties of education should be reflected in teacher training programs. Faculties should be allowed to form their unique teacher training culture. Through piloting studies, shortcomings of the programs should be corrected. Then they implemented. The programs should undergo a comprehensive evaluation during and at the end of the process.

Other criticized aspects of the 2018 initial teacher training programs are the decrease in the class hours of some courses, the need for the approval of HEC to open a new elective course in content knowledge and 
pedagogical content knowledge fields and limitation of these elective courses to six. This makes it difficult for faculty members to propose new courses and to cover the contents of the courses whose class periods have been shortened. Therefore, the requirement of HEC approval to propose a new elective course should be abolished and the class periods allocated to courses can be increased. Another important issue related to the courses is the abolition of the class periods allocated to practice. It is important that the courses be applied in the acquisition of the skills required for the effective rendering of the teaching profession. Pre-service teachers can be provided with the opportunity to practice what they have learned in the theoretical parts of the courses.

Important classes in which teaching profession skills are acquired are teaching practice courses. In the new programs, the school experience course was abolished and the duration of the teaching practice course was doubled. However, the faculty members did not find this adequate. It is thought that this course should be arranged in such a way that pre-service teachers will be engaged in practice throughout a whole term. Within the context of the teaching practice course, one instructor was asked to advice up to eight pre-service teachers and to observe each of them four times. Observing eight students four different times requires the instructor to go to school 32 times. This does not seem realistic considering the workload of instructors. Therefore, the regulation needs to be reviewed. The school experience course is as important as the teaching practice course because in this course, pre-service teachers get to know the profession and decide whether or not to become a teacher. The abolition of the course may lead to problems in terms of getting to know and preparation for the profession. For this reason, the school experience course can be put back into the programs.

The current study was conducted with the participation of faculty members working in the education faculty of a state university located in the western part of Turkey. The study can be repeated with a study group consisting of faculty members from different education faculties from different parts of Turkey. The results to be obtained from program evaluation studies to be conducted in the process of the implementation of the teacher training programs and at the end of the first four years can be compared with the results of the current study.

\section{Acknowledgement}

This study was presented in the 6th International Congress on Curriculum and Instruction held in Kars Turkey between 11-13 October 2018 as oral presentation. 


\section{TÜRKÇE SÜRÜM}

\section{Giriş}

Toplumların bilimsel, ekonomik ve kültürel olarak gelişiminin yetiştirilen öğretmenlerin niteliği ile doğru orantılı olduğu söylenebilir. Alanyazın incelendiğinde çalışmaların bu görüşü desteklediği görülmektedir (Cruickshank vd., 1996; Darling-Hammond, 2006; TEDMEM, 2014; Yıldırım, 2013). Nitelikli öğretmen yetiştirme Türkiye Cumhuriyeti'nin eğitim alanındaki önemli amaçları arasında yer almaktadır. Bunun gerçekleştirilmesi için öğretmen eğitimi lisans programları, içinde bulunulan dönemin gereklerine göre gözden geçirilerek güncellenmektedir. Öğretmen yetiştirme programlarında yapılan düzenlemeler nitelikli öğretmen yetiştirmeyi amaçlasa da bu amacın gerçekleştirilebildiğini söylemek mümkün değildir (Atanur-Baskan, 2001; Safran, 2014; Yıldırım 2011). Ancak uygulama odaklı ve toplumun kalkınmasına yönelik öğretmen yetiştiren Köy Enstitülerinin bu genel tablodan farklı olduğu düşünülmektedir.

Türkiye'de, ilköğretmen okulları, eğitim enstitüleri, köy eğitmen kursları, köy öğretmen okulları ve köy enstitüleri ile ilkokula öğretmen yetiştirilmiştir (Altunya, 2005; Ataünal, 1987; Ataünal, 1994; Cicioğlu, 1983; Milli Eğitim Bakanlığı (MEB), 1995; Öztürk, 1996; Öztürk, 1998; Öztürk, 2005; Özalp \& Ataünal, 1977; Yüksek Öğretim Kurulu (YÖK), 1998). Ortaokullara ise, eğitim enstitüleri, yüksek öğretmen okulları, deneme yüksek öğretmen okulları ve üniversitelerde öğretmen yetiştirilmiştir (Kavcar, 2002; Oğuzkan, 1983; Şahin, 2006; Tambağ, 2007; Uçan, 1982; YÖK, 1998). 1982'de Öğretmen yetiştirme görevinin üniversitelere devredilmesiyle eğitim fakültelerinde eğitim bilimleri ve öğretmen yetiştirmeyle ilgili akademik çalışmalar da yapılmaya başlanmıştır (YÖK, 2007).

Öğretmen yetiştirme görevinin eğitim fakültelerine devredilmesinin ardından 1997 ve 2006 yılları arasında öğretmen yetiştirme lisans programlarında kapsamlı güncellemeler yapılmıştır. Bunlardan ilkinde 1997 yıllında Dünya Bankası'nın desteklediği Milli Eğitimi Geliştirme Projesi kapsamında hizmet öncesi öğretmen yetiştirme süreci yapılandırılmıştır. Bu yapılanmada, eğitim bilimlerinin bazı lisans programları işlevsiz olduğu gerekçesiyle kapatılmıştır. Sekiz yıllık zorunlu eğitime geçilmesi nedeniyle okul kademeleri sekiz yıllık ilköğretim ve üç yıllık ortaöğretim olarak düzenlenmiştir. Eğitim fakülteleri zorunlu ilköğretimin gereksinimlerini karşılamak üzere yapılandırılmıştır. Fakültelerdeki bölümler ve anabilim dalları ders programları yeniden oluşturulmuştur. Bu programlarda öğretmen yeterlikleri üzerinde durulmuş ve derslere uygulamalar eklenmiştir. Böylece öğretmen adaylarından öğretmenliğe ilişkin bilgi ve becerilerini gerçek ortamda pekiştirmeleri beklenmiştir. Yan dal programları ile öğretmen adaylarının farklı öğretmenlik alanlarında yetkinlik kazanmalarına fırsat verilmiştir. (YÖK, 1998, 2007, 2018). Ancak bu programlar kuramsal derslere ağırlık verilmemesi ve öğretmen adaylarının genel kültür ve alan bilgisi konusunda yetişmesine neden olduğu gerekçeleriyle kabul görmemiştir. 1997 yapılanmasını değerlendiren Eşme (1998), bölüm yapılanmalarını gerçekçi bulmamış, eğitim fakültelerindeki niteliğin düşeceğini, alan derslerinin tezsiz yüksek lisans nedeniyle devre dışı kalacağını ve yan alanın istihdamda zorluklar yaratacağını belirterek programı eleştirmiştir. Kavcar (2003) yeni yapılanmanın branş öğretmeni yetiştirmede sorunlara neden olacağını, bu konuda acil önlemlerin alınması gerektiğini belirtmiştir. Ataman (1998) ise bu modelde uzun yıllara dayanan öğretmen yetiştirme deneyiminin dikkate alınmadı̆̆ını belirtmiştir.

1997 yılında hazırlanan ve 1998 yılında uygulanmaya başlanan programların ardından 2006 yılında öğretmen yetiştirme lisans programlarının yeniden güncellenmesi gündeme gelmiştir. 1997 yapılanmasındaki aksayan yönler gözden geçirilmiş; ilköğretim ve ortaöğretim alan öğretmenliği programlarında bulunan meslek bilgisi dersleri düzenlenmiştir. Programlardaki genel kültür derslerinin sayısı artırılmış, programlarda yer alan ortak derslerin dışında kalan yaklaşık \%25 oranındaki derslerin belirlenme yetkisi üniversitelere verilmiştir. Programlar, \%50-60 alan bilgisi, \%25-30 meslek bilgisi ve \%15-20 genel kültür derslerinden oluşmuştur. Programlarda genel kültür derslerinin oranları arttırılmıştır. Buna karşın uygulama dersleri azaltılmıştır (YÖK, 2007, 2018). Bazı programlarda çekirdek derslerin fazlalığı nedeniyle, seçmeli ders sayısı daha da artırılmıştır. Bunun amacı, üniversitede yetiştirilen öğretmen adayına aydın bir kişide bulunması gereken entelektüel donanımın kazandırılması olarak belirtilmiştir. Bunun yanı sıra programların Avrupa Birliği öğretmen yetiştirme programlarıyla örtüştüğü belirtilmiştir (YÖK, 2007b).

2006-2007 eğitim öğretim yılından itibaren uygulanan öğretmen yetiştirme lisans programları 2018 yılında tekrar güncellenmiştir. Yapılan değerlendirmeler sonucu, alan eğitimine yönelik derslerle öğretmenlik meslek bilgisi derslerinin yeniden oluşturulması ve programlarda bunlara ağırlık verilmesi gereği ifade edilmiştir. Ayrıca, 
ortaöğretim alan öğretmenlikleriyle ilgili lisans programlarının fakülteler arasında farklılıklar gösterdiği belirtilmiştir. Programların Öğretmenlik Mesleği Genel Yeterlikleri ve Öğretmen Stratejisi, 10. Kalkınma Planı, MEB 2015-2019 Stratejik Planı, Türkiye Yükseköğretim Yeterlikler Çerçevesi (TYÇ), Öğretmen Yetiştirme ve Eğitim Bilimleri Alan Yeterlikleri gibi resmi belgelerle uyum sağlanmasının önemine vurgu yapılmıştır. Eğitim fakültelerinde kalite ve akreditasyon çalışmalarının yeniden başlatılması, Avrupa yükseköğretim alanında Bologna sürecine uyum ve dünyadaki gelişmelere paralel olarak ortak çekirdek programlar oluşturulmasına gereksinim duyulduğu ifade edilmiştir. İçeriği benzer olup farklı isimlerle farklı öğretmen yetiştirme programlarında yer alan seçmeli derslerin ortak bir seçmeli ders havuzunda toplanmasının, programlardan mezun olacak öğretmen adaylarının çok yönlü rol model olmasının ve araştırmacı öğretmen niteliği kazanmış olarak mezun olmasının hedeflenmesi 2018 programlarının güncellenme gerekçeleri olarak gösterilmiştir (YÖK, 2018).

Güncellenen öğretmen yetiştirme lisans programlarının, program geliştirme komisyonlarının oluşturulması, alan taraması yapılması ve program güncelleme süreci olmak üzere üç aşamada hazırlandığı ifade edilmiştir. Program geliştirme sürecinde her lisans programı için üç-beş üyeden oluşan komisyonlar (Eğitim Programları ve Öğretim-Alan eğitimcisi mutlaka olacak şekilde) oluşturulduğu ifade edilmiştir. Öğretmenlik Meslek Bilgisi ve Genel Kültür Dersleri için ayrı komisyonlar oluşturulduğu belirtilmiştir. Komisyonların, mezunlar, veliler, okul müdürleri, öğretmenler ve öğretim elemanlarıyla görüşmeler yaptığı ifade edilmiştir. Türkiye Yükseköğretim Yeterlilikler Çerçevesi, Öğretmen Yetiştirme ve Eğitim Bilimleri Alan Yeterlikleri ve MEB Öğretmenlik Mesleği Yeterliklerinin incelendiği vurgulanmıştır. 2018 Öğretmen Yetiştirme Lisans Programlarındaki derslerin adı, içeriği, haftalık saati ve kredisi (yerel kredi ve AKTS) güncellenmiştir. Öncelikle 2006 öğretmen yetiştirme programlarından çıkarılması, birleştirilmesi ve eklenmesi gereken derslerin belirlendiği, daha sonra yeni programlarda yer alacak derslerin adı, içeriği, haftalık ders saati ve kredisinin (yerel kredi ve AKTS) güncellendiği belirtilmiştir. Hazırlanan taslak programlara ilişkin MEB’ten görüş alınmıştır. Daha sonra, Öğretmen Yetiştirme Çalışma Grubuna sunulmuş ve Yükseköğretim kurulu (YÖK) tarafından onaylanmıştır. Eğitimin paydaşları ile Türkiye'nin çeşitli bölgelerinde programların güncellenmesi sürecinde çalıştaylar ve toplantılar yapıldığı belirtilmiştir. YÖK'e (2018) göre, 2018 lisans programlarının getirdiği yenilikler şu şekilde özetlenebilir: Programlarda öğretmenlik meslek bilgisi \%30-35; genel kültür \%15-20 ve alan eğitimi \%45-50 oranında yer almıştır. Öğretmen yetiştirme programları arasında çekirdek program oluşturulmuştur. Tüm lisans programlarında öğretmenlik mesleğiyle ilgili dersler, yeniden düzenlenmiştir. Eğitim Bilimine Giriş, Bilimsel Araştırma Yöntemleri gibi derslerin adları değiştirilmiş, "Sınıf Yönetimi”, "Öğretim İlke ve Yöntemleri”, "Eğitim Psikolojisi", gibi derslerinin adları aynı kalmış ancak haftalık ders saatleri azaltılmıştır. Okul deneyimi dersi programlardan çıkarılarak, Öğretmenlik Uygulaması Dersi I ve II olarak iki döneme uzatılmıştır. Programlara "Eğitim Sosyolojisi", "Türk Eğitim Tarihi”, "Eğitim Felsefesi” dersleri, lisans programlarının tamamında ortak meslek dersleri olarak yer almıştır. Programlardaki seçmeli derslere ek olarak, meslek bilgisi ve alan eğitimi seçmeli ders havuzuna öğrencilerin ilgi, istek ve gereksinimleri doğrultusunda YÖK'ten onay alınarak en fazla altı ders, genel kültür seçmeli derslerine ise üniversite senato kararıyla dersler eklenebileceği belirtilmiştir. Güncellenen öğretmen yetiştirme lisans programları, 2018-2019 eğitim öğretim yılında birinci sınıflardan itibaren uygulanmaya başlanmıştır.

Eğitim programları, bir toplum için yetiştirilecek bireylerin özelliklerinin belirlenmesini sağlar. Programların nitelikli olması, eğitimin nitelikli olmasının en önemli koşullarından biridir. Çünkü niteliksiz programlar nitelikli bir eğitim gerçekleşmesini sağlayamaz (Gözütok, 2001). Programların eksikliklerinin giderilmesi, eğitimin niteliğini de artırır. Ĕgitim programlarının daha etkili hale getirilmesi için programların değerlendirilmesi gerekir (Erden,1998). Program değerlendirme, "tasarlanan ve uygulanan bir eğitim programının etkililiği hakkındaki bilgilerin toplandığı, analiz edilip yorumlandığı ve sonuçta programın sürdürülmesi, geliştirilmesi ya da sonlandırılması kararının alındığı bir süreç" (Sağlam \& Yüksel, 2007, p. 176) olarak tanımlamaktadır. Program değerlendirmede, programın amaçlarına, içeriğin öğrenci düzeyine uygunluğuna, öğretim yöntem, teknik ve materyallerin doğru seçilip seçilmediğine, belirlenen amaçlara ne derece ulaşıldığına bakılır (Saylor \& Alexander, 1974). Program değerlendirmede, programın devamı, gözden geçirilip geliştirilmesi ya da bitirilip yerine yeni bir programın geliştirilmesi söz konusu olabilir (Ornstein \& Hunkins, 2004).

Programların değerlendirilmesinde programları uygulayanların görüşlerinin bilinmesi, programların planlandığı şekilde hayata geçirilmesi için önemlidir. Uygulayıcılar olarak öğretim üyelerinin görüşlerinin alınması programların kabul görmesi ve planlandığı şekilde uygulanması ve başarıya ulaşması açısından önemlidir. Tanıtım dokümanında YÖK başkanının "YÖK olarak bizlerin bu düşüncelerini, öğretmen eğitiminde rol alan öğretim elemanlarının ve bu süreçte okullarda rehberlik yapacak öğretmenlerimizin, okul ve sınıf 
ortamlarına taşıyarak hayata geçireceğini ümit ediyorum." ifadesi öğretim elemanlarının üstlendiği sözü edilen kilit rolü açıkça göstermektedir.

2018-2019 eğitim öğretim yılında uygulanmaya başlanan programların öğretim üyelerinin bakış açılarıyla ve deneyimleriyle değerlendirilmesinin yararlı olacağı düşünülmektedir. Elde edilen sonuçların programların yeniden güncellenmesi sürecinde yararlı olacağı öngörülmektedir. Bu nedenle araştırmada 2018 öğretmen yetiştirme lisans programlarının değerlendirilmesi amaçlanmıştır. Bu amaç doğrultusunda aşağıdaki sorulara yanıt aranmıştır.

Öğretim üyelerinin;

1. 2018 öğretmen yetiştirme lisans programlarının geliştirme sürecine ilişkin görüşleri nelerdir?

2. 2018 öğretmen yetiştirme lisans programlarındaki değişikliklere ilişkin görüşleri nelerdir?

3. 2018 öğretmen yetiştirme lisans programlarının nitelikli öğretmen yetiştirmeye katkılarına ilişkin görüşleri nelerdir?

4. 2018 öğretmen yetiştirme lisans programlarındaki öğretmenlik uygulamalarına ilişkin görüşleri nelerdir?

Yöntem

\section{Araştırma Deseni}

$\mathrm{Bu}$ araştırmada, nitel araştırma desenlerinden temel yorumlayıcı desen kullanılmıştır (Merriam, 2013). Bu desende, katılımcıların deneyimleri, araştırılan konuya ya da sürece ilişkin algıları, dünya ile etkileşirken yaşadıkları deneyimleri anlamlandırılmaya çalışılır. Başka bir deyişle, katılımcıların araştırma sürecine ilişkin oluşturdukları anlam ve yansımalar dikkate alınır. Temel yorumlayıcı desendeki araştırma sürecinde amaç veri kaynağı olan katılımcının bir durum ya da olayı nasıl anlamlandırdığının belirlenmesidir (Altheide \& Johnson, 2011). Bu çalışmada temel yorumlayıcı nitel araştırma deseni, 2018-2019 eğitim öğretim yılından itibaren eğitim fakültelerinde uygulanmaya başlanan öğretmen yetiştirme lisans programlarını öğretim üyelerinin bakış açıları ve deneyimlerine dayalı olarak yenilenen programların değerlendirilmesi amaçlandığından tercih edilmiştir. Böylece öğretim üyelerinin programlara ilişkin deneyimleri doğrultusunda 2018 öğretmen yetiştirme lisans programlarına yönelik görüşlerinin derinlemesine incelenmesi ve bu bağlamda oluşturdukları anlam ve yorumlamalarının ayrıntılı bir biçimde betimlenmesi söz konusu olmuştur.

\section{Çalışma Grubu}

Araştırmanın katılımcılarını Türkiye'nin batı bölgesinde yer alan bir üniversitenin eğitim fakültesinde çalışan öğretim üyeleri oluşturmuştur. Katılımcılar arasında fen bilgisi, okul öncesi, sınıf, özel eğitim bilgisayar ve öğretim teknolojileri, matematik, Türkçe, sosyal bilgiler, müzik, resim iş, İngilizce eğitimi, Almanca ile rehberlik ve psikolojik danışmanlık, eğitim programları ve öğretim, eğitim yönetimi anabilim dallarında çalışan ve araştırmaya katılmaya gönüllü olan 32 öğretim üyesi yer almıştır. Öğretim üyelerinin seçiminde amaçlı örnekleme yöntemlerinden maksimum çeşitlilik örnekleme kullanılmıştır. Her bölümden farklı mesleki kıdemlerden (3 ile 25 yıl), farklı akademik unvanlardan öğretim üyelerinin çalışma grubunda yer almasına dikkat edilmiştir. Sonuç olarak çalışma grubunu oluşturan öğretim üyelerinin 12'si doktor öğretim üyesi, 10'u doçent ve 10'u profesör iken, 18'i erkek 14'ü kadındır.

\section{Veri Toplama Yöntemi ve Aracı}

Eğitim fakültesindeki öğretim üyelerinin güncellenen öğretmen eğitimi lisans programlarına ilişkin görüşlerinin belirlenmesi için yarı yapılandırılmış görüşme formu hazırlanmıştır. Görüşme soruları, öğretim üyelerinin güncellenen programlara ilişkin görüşlerinin belirlenmesi, programların kendileri için anlamını ve önceki deneyimlerinden hareketle yeni programlara ilişkin derinlemesine bilgi edinilmesi ve bu bilginin anlamlandırıması için hazırlanmıştır. Araştırmanın amaçları doğrultusunda bir soru havuzu oluşturulmuş ve bu havuzdan sorular seçilerek görüşme formu oluşturulmuştur. Bu form için uzman görüşü alınmış ve uzmanların görüşleri doğrultusunda form yeniden düzenlenmiştir. Düzenlenen görüşme formu üç öğretim üyesine uygulanarak deneme uygulaması yapılmıştır. Bu uygulamanın ardından veri toplama aracı son şeklini almıştır. Görüşme formunun son halinde beş soruya yer verilmiştir. Sorulara örnek olarak, 2018 öğretmen yetiştirme programlarının hazırlanma sürecine ilişkin görüşleriniz nelerdir? ve 2018 öğretmen yetiştirme lisans programlarındaki değişikliklere ilişkin görüşleriniz nelerdir? verilebilir. 


\section{Veri Toplama Süreci}

Verilerin toplanması için araştırmanın yapılacağı fakültenin dekanlığından izin alınmıştır. Ardından, eğitim fakültesinde görüşme süreci başlatılmıştır. Araştırmacılar, görüşülmesi planlanan öğretim üyelerine araştırmanın amacı ve kapsamı hakkında bilgi vermiştir. Araştırma için gönüllü olup olmadıkları sorulmuştur. Görüşmeyi kabul eden öğretim üyeleri ile görüşmenin yapılacağı tarih ve saat belirlenmiştir. Ardından öğretim üyeleri ile görüşmeler gerçekleştirilmiştir. Görüşmeden önce katılımcılardan ses kaydı için izin alınmıştır. Görüşmeler kendilerini rahat bir biçimde ifade edebilmeleri için öğretim üyelerinin odalarında yapılmıştır ve 20 ile 30 dakika arasında sürmüştür. Görüşmeler ses kayıt cihazıyla kayıt altına alınmıştır. Ses kayıtları, öğretim üyelerine verilen kodlarla bilgisayar ortamına aktarılmıştır. Ses kayıtları ve deşifreler şifreli bir bilgisayardaki şifreli bir dosyada saklanmaktadır.

\section{Verilerin Analizi}

Görüşme kayıtları, katılımcıların görüşlerine bağı kalınarak çözümlenmiştir. Öğretim üyeleri ile yapılan görüşmelerden elde edilen veriler tümevarımsal içerik analizine dayalı olarak çözümlenmiştir. Ses kayıt cihazı ile kaydedilen veriler deşifre edilerek bilgisayar ortamına aktarılmış, ardından birkaç kez okunmuş ve iki döngüde kodlanmıştır. Birinci döngüde verilere, açık ve in-vivo kodlama, ikinci döngüde ise, eksen kodlaması yapılmıştır. Daha sonra, belirlenen temalar altındaki kodların birbirleriyle ilişkileri açıklanarak yorumlanmış, doğrudan alıntılara yer verilerek neden sonuç ilişkileri irdelenmeye çalışımıştır.

\section{Geçerlik ve Güvenirlik Çalışmaları}

Araştırmanın inanılırlığı, aktarılabilirliği, teyit edilebilirliği ve tutarlığı için uzman incelemesi, ayrıntılı betimleme, çalışma grubunun oluşturulması ve sonuçların teyit ettirilmesi stratejileri kullanılmıştır (LeCompte \& Goetz, 1982; Linkoln \& Guba, 1985; Patton, 2014; Tedlie \& Tashakkori, 2009). Araştırma kapsamında nitel araştırma yöntemleri konusunda uzman bir araştırmacı ile toplantı yapılmış ve araştırma sürecine ilişkin bilgiler verilmiştir. Araştırma sonuçları da uzmanla paylaşılarak araştırmacıların yaklaşım ve düşünme biçimlerinin geçerliği uzmanla birlikte değerlendirilmiştir. Araştırmanın aktarılabilirliğinin sağlanması için ayrıntılı betimleme kullanılmıştır (Lincoln \& Guba, 1985; Meriam, 2013; Teddlie \& Tashakkori, 2009; Yıldırım \& Şimşek, 2013). Katılımcıların seçilme süreci ve özellikleri, verilerin toplanması, analizi ve araştırmacının rolü araştırmanın yöntem bölümünde ayrıntılı olarak açıklanarak aktarılabilirlik sağlanmıştır. Bunun yanı sıra, görüşme yapılacak bireylerin seçiminde çeşitlilik sağlanması için her anabilim dalından farklı kıdem ve unvanda öğretim üyesi ile görüşülmüştür. Ayrıca, araştırmadaki bulgular yorum yapılmaksızın sunulmuş ve temalar doğrudan alıntılarla desteklenmiştir. Tutarlılık için verilerin analizi sürecinde nitel araştırma ve öğretmen eğitimi konusunda uzman başka bir araştırmacıdan yardım alınmış ve sonuçlar teyit ettirilmiştir. Bu çerçevede uzmandan her bir veri metnine ilişkin oluşturulan temaların ve alt temaların uygunluğu konusunda görüş bildirmesi istenmiştir. Görüş ayrılığı olan temalar ve kodlar üzerinde tartışılarak uzlaşma sağlanmıştır.

\section{Araştırmacıların Rolü}

Çalışmayı yürüten araştırmacılar eğitim fakültesinde uzun bir süredir öğretim elemanı olarak çalışmaktadırlar. Her iki araştırmacının da öğretmen eğitimi ve nitel araştırma konusunda çalışmaları bulunmaktadır. Dolayısıyla araştırma konusu ve nitel araştırmalar konusunda deneyimli oldukları söylenebilir. Öğretmen eğitimi programlarının güncellenmesi ve fakültelere duyurulmasının ardından çalışmanın hazırlıklarına başlanmıştır. Önce çalışmanın çerçevesi belirlenmiş, ardından ilgili alanyazın incelenmiş, veri toplama aracı hazırlanmıştır. Görüşme sorularının hazırlanmasından araştırmanın raporlanmasına kadar geçen süreç, nitel araştırma konusunda uzman araştırmacılar tarafından gerçekleştirilmiştir.

\section{Bulgular}

2018 öğretmen yetiştirme lisans programlarının değerlendirildiği bu araştırmada, bulgular araştırma soruları doğrultusunda, öğretim üyelerinin öğretmen yetiştirme lisans programlarının hazırlanma (geliştirilme) süreci, nitelikli öğretmen yetiştirmeye katkısı, getirdiği yenilikler ve okul uygulamaları ile ilgili görüşleri başlıkları altında toplanmıştır. Görüşlerin ayrıntıları tablolar halinde aşağıda verilmiştir. Öğretim üyelerinin öğretmen yetiştirme lisans programlarının hazırlanmasına ilişkin görüşleri Tablo 1'de verilmektedir.

Tablo 1'de öğretim üyelerinin 2018 öğretmen yetiştirme lisans programlarının hazırlanışına ilişkin görüşleri yer almaktadır. Görüşler, program geliştirme sürecine, program geliştirme sürecindeki komisyonlara ve YÖK'e ilişkin eleştiriler ile program hazırlama sürecine ilişkin önerileri kapsamaktadır. 
Tablo 1

2018 Öğretmen Yetiştirme Lisans Programlarının Hazırlanmasına iliş̧kin Görüşler

\begin{tabular}{|c|c|}
\hline Temalar/Kodlar & $f$ \\
\hline Programın Hazırlanmasına İlişkin Görüşler & 75 \\
\hline Program Geliştirme Sürecine İlişkin Genel Görüşler & 14 \\
\hline Programların tam olarak program geliştirme sürecine göre hazırlanmaması & 4 \\
\hline Programların öğretmen yetiştirme sürecinin gereksinimlere göre geliştirilmemesi & 4 \\
\hline Program geliştirme çalışmalarının planlı yapılmaması & 3 \\
\hline Program geliştirme sürecinin merkezi olarak yürütülmesi & 3 \\
\hline Program Geliştirme Sürecinde Komisyonlara İlişkin Görüşler & 31 \\
\hline Komisyonlara davetlerde şeffaflık olamaması & 7 \\
\hline Komisyonlarda alınan kararların programa yansımaması & 6 \\
\hline Bazı komisyon üyelerinin sempozyuma çağırılmaması & 5 \\
\hline Komisyonda alınan kararların sempozyumda değiştirilmesi & 4 \\
\hline Komisyonda alınan kararların çoğulcu olmaması & 3 \\
\hline Komisyonda eğitim bilimcilerin görüşlerin çok dikkate alınmaması & 3 \\
\hline Alan eğitimcilerin sayısının fazla olması & 1 \\
\hline Alan eğitimcilerinin görüşlerinin baskın olarak yansıması & 1 \\
\hline Alan eğitimcilerinin değişime dirençli olması & 1 \\
\hline Program Geliştirme Sürecinde YÖK'e İlişkin Görüşler & 24 \\
\hline Eğitim fakültelerine akademik özerklik sağlamaması & 7 \\
\hline Tek tip öğretmen yetiştirmeye odaklanılması & 5 \\
\hline Merkezi olarak öğretmen yetiştirmeye odaklanması & 4 \\
\hline YÖK'ün öngördüğü içeriklerin yazılması & 3 \\
\hline YÖK'ün paydaşlardan kapsamlı görüş almaması & 2 \\
\hline Paydaşlardan toplanan görüşlerin programlara yansımaması & 1 \\
\hline Öğretmen yetiştirmede ekolleşmenin dikkate alınmaması & 1 \\
\hline Programların merkezi olarak yapılmasının işlevsel olmaması & 1 \\
\hline Program Hazırlama Sürecine iliş̧kin Öneriler & 6 \\
\hline Üniversitelerde taslak programlar hazırlanmalı & 1 \\
\hline Eğitim fakültelerinin kendi değişikliklerini yapması sağlanmalı & 1 \\
\hline Çalıştaylarda paydaşların görüşleri alınmalı & 1 \\
\hline Programların pilot uygulamaları yapılarak değerlendirilmeli & 1 \\
\hline Programların eksikleri belirlenerek program geliştirme sürecine veri sağlanmalı & 1 \\
\hline Üniversitelerde program geliştirme uzmanı olmalı ve programların uygulamasını denetlemeli & 1 \\
\hline
\end{tabular}

Öğretim üyelerinin öğretmen yetiştirme lisans programlarının hazırlanma sürecine ilişkin görüşlerinin genelde olumsuz olduğu görülmektedir. Öğretim üyeleri, programların tam olarak program geliştirme sürecine $(\mathrm{f}=4)$ ve alanın gereksinimlerine göre hazırlanmadığını $(\mathrm{f}=4)$ belirtmişlerdir. Program geliştirme sürecindeki çalışmaların planlı yapılmamasını $(f=3)$ ve programların merkezi olarak hazırlanmasını $(f=3$ ) eleştirmişlerdir. Bulgulara ilişkin doğrudan alıntılar aşağıda verilmiştir.

K8: Program geliştirme anlayışı ülkemizde tam olarak oturmadı. (Programlar) Program geliştirme mantığıyla hazırlansaydı, okuldaki yaşanan sorunlar (programlarda) daha iyi ortaya çıkardı.

K11: YÖK lisans programlarını merkezi olarak güncelledi ama biz iki ay ne yaptık? Yine onların direttiği derslere içerik yazdık.

K9: Gerçekten görüşler alınmış olsa... Belki kafalarındaki merkeziyetteki görüşü onaylamak için yapılıyor, o da (programa) yansımıyor. Ben daha önceki programlara da görüş bildirdim, çok da yansımadı programlara.

K2: Alanın duayeni dediğimiz üç ya da dört tane hocası var. Alana önderlik eden ve bu hocaların da hiçbirisi yoktu bu programın içerisinde.

Farklı program komisyonlarında yer alan öğretim üyeleri, komisyonlarda görüşlerinin yeterince dikkate alınmadığını belirtmişlerdir. Öğretim üyeleri, program komisyonlarına davetlerde şeffaflık olmadığını $(f=7)$, 
komisyonda alınan kararların programa yansımadığını $(f=6)$, bazı komisyon üyelerinin daha sonraki bazı toplantılara çağıııımadığını $(f=5)$ komisyonlarda alınan kararlardan bazılarının daha sonra yapılan sempozyumda değiştirildiğini $(f=4)$ belirtmişlerdir. Bunun yanı sıra komisyonlarda alınan kararların çoğulcu olmadığını $f=3$ ) ve eğitim bilimcilerin görüşlerinin dikkate alınmadığını $(f=3)$ ifade etmişlerdir. Bunun nedeni olarak komisyondaki alan eğitimcilerinin sayısının fazla olması, bunların görüşlerinin baskın olarak programlara yansıması, alan eğitimcilerinin değişime dirençli olmaları ve alanlarına sahip çıkmak için çok katı olmaları gösterilmiştir. Bulgulara ilişkin doğrudan alıntılar aşağıda verilmiştir.

K9: Eskişehir'deki sempozyumda ya bir yerden tepki geldi ya da bilmiyorum YÖK'te ne oldu. O program için bir değişiklik oldu. Bizim düşündüğümüz o ilk komisyondakinden farklı sonuçlar oldu.

K8: Söylenenler farklı çıkıyor, oradaki fikirler yansımıyor. Birde oraya çağırılanlar neye göre çağırılıyor, o da belli değil.

K11: Çoğunluğun söylediği daha çok dikkate alındığı için benim söylemlerim geri planda kaldı.

K5: Bazı derslerle ilgili görüş bildirtmiştik özellikle. Onlarla ilgili herhangi bir değişiklik yapılmadı.

K11: Dinlemek istemedikleri (alan eğitimcileri) de gayet açık ve netti. Onlara göre, özellikle lisans programlarında alan dersleri düzenli bir şekilde olsun, meslek bilgisi, eğitim bilimleri dersleri de bir yerlerde olsun algısı vardı. O yüzden (görüşlerimin) dikkate alındığını pek düşünmüyorum.

Öğretim üyeleri, programların YÖK tarafından hazırlamasına yönelik eleştirilerde de bulunmuşlardır. Programların merkezi olarak hazırlanması ile eğitim fakültelerine özerklik sağlanamadığını ( $f=7$ ), bu durumun tek tip öğretmen yetiştirilmesine neden olduğunu $(f=5)$ ve merkezi öğretmen yetiştirmeye odaklanıldığını $(f=4)$ belirtmişlerdir. Programlara YÖK'ün öngördüğü içeriklerin yazıldığını $(f=3)$, paydaşlardan kapsamlı görüş alınmadığını $(f=2)$, alınan görüşlerin de programlara yansıtılmadığını $(f=1)$, bu durumun öğretmen yetiştirmede ekolleşmenin dikkate alınmamasına neden olduğunu $(f=1)$ ve öğretmen yetiştirmede özerkliğin sağlanmadığını ifade etmişledir. Bu şekilde hazırlanan bir programın işlevsel olamayacağını $(f=1)$ vurgulamışlardır. Bulgulara ilişkin doğrudan alıntılar aşağıda verilmiştir.

K7: Tek tip... Onu demek istiyorum, tek bir çerçevede... Bu da işlemiyor tabii ki her anabilim dalında dediğim gibi beklenti başka, profil başka, ilgili alanın gerektirdikleri başka olduğu için tek tip ne kadar çözüm olacak? Olmayacak...

K11: Öğretmen yetiştirme lisans programı YÖK tarafından merkezi olarak değiştirildi. İlk toplantıda bir kişi de olsam söz hakkına sahiptim, Ama ikinci ... toplantıdan haberdar bile edilmedim.

K17: Merkezden çerçeve olarak gelmesi tabi ki işi daha da zorlaştırıyor. İşlevselliğini azaltıyor. Yereli temel alarak düşünmek ya da verilen görüşleri göz önünde bulundurup iyileştirme yapılsaydı daha çok öğrenciye hitap eden, daha işlevsel ve etkili (program) olacaktı.

Öğretim üyeleri program hazırlama sürecindeki sorunların çözülmesine yönelik önerilerde bulunmuşlardır. Üniversitelerin de taslak programlar hazırlamasını $(f=1)$, fakültelerin kendi değişikliklerini daha fazla yapmasını $(f=1)$, çalıştaylarda paydaşların görüşlerinin geniş kapsamlı olarak alınmasını $(f=1)$, programların pilot uygulamaları yapılarak değerlendirilmesini $(f=1)$, eksiklerin belirlenerek program geliştirme sürecine veri sağlanmasını $(f=1)$ ve üniversitelerde program geliştirme uzmanı olmasını ve programların uygulanışının denetlenmesini $(f=1)$ önermişlerdir. Bulgulara ilişkin doğrudan alıntılar aşağıda verilmiştir.

K8: Merkezileşmeden çok, okullarda, mesela üniversitelerde, bölümlerde bir taslak oluşturulup o taslağın, üniversitelere gönderilmesi ve sonra YÖK'e kadar giden toplantılar yapılmalıdır.

K25: Mutlaka görüşlerin alınarak, en alttan başlayarak üste gitmesi gerekiyor.

K16: Önce üniversitelerden programla ilgili değerlendirmeler alınıp eksikleri belirlenmelidir. Sorunlar her üniversiteden gelen görüşler doğrultusunda, sorunların üzerinden tartışılıp kurultaylarda tartışılmalıdır. Bir de araştırma sonuçları ve yapılan çalışmalar, öğrencilerden de görüş alınıp, öğretmenlerden ve o çıkan görüşlerin de oraya yansıtıldığı bir süreç daha sağlıklı olur. Biz programı hemen uyguluyoruz, bir daha yıllarca değerlendirmiyoruz. 10-20 yıl sonra değerlendiriyoruz. Oysa programı uygulayıp eksik görülenleri yeniden düzenlememiz gerekir. 
Öğretim üyelerinin 2018 öğretmen yetiştirme lisans programlarındaki değiş̧ikliklere ilişkin görüşleri Tablo 2 'de verilmiştir.

\section{Tablo 2}

Öğretmen Yetiştirme Lisans Programlarındaki Değişikliklere ilişkin Görüşler

\begin{tabular}{|c|c|}
\hline Temalar/Kodlar & $\mathbf{f}$ \\
\hline İçeriğe İlişkin Genel Görüşler & 75 \\
\hline Ders sürelerinin azaltılması & 20 \\
\hline Ders saati ve uygulama saati uyumsuzluğu & 16 \\
\hline Ders sayısının fazla olması & 15 \\
\hline Der içeriklerinin genelde aynı kalması & 14 \\
\hline Bazı derslerin birbirinin tekrarı olması & 9 \\
\hline Eğitim sosyolojisi ve eğitim felsefesi derslerinin konulmasının faydalı bulunması & 1 \\
\hline Seçmeli derslere iliş̧kin Görüşler & 35 \\
\hline Seçmeli Derslere ilişkin Olumlu Görüşler & 17 \\
\hline Seçmeli derslerin sayısının artması & 10 \\
\hline Seçmeli derslerin çokluğunun özgürlükçü bir yaklaşım olması & 7 \\
\hline Seçmeli Dersler İçin Olumsuz Görüşler & 17 \\
\hline Seçmeli dersler için öğretim elamanı sayısının yeterli olmaması & 5 \\
\hline Seçmeli derslerin açılması için YÖK onayının sınırlandırıcı olması & 4 \\
\hline Seçmeli derslerin hangi alan uzmanları tarafından verileceği sorunu & 3 \\
\hline Gerçeklerle uyuşmayan uygulamalar & 2 \\
\hline Farklı bir seçmeli ders önermenin sınırlandırılmış olması & 1 \\
\hline Derslerdeki uygulamaların azaltılması & 1 \\
\hline Bazı derslerin sadece adının değişmesi & 1 \\
\hline Alan, Meslek ve Genel Kültür Derslerinin Uyumu & 39 \\
\hline Alan Bilgisi Derslerine ilişkin Görüşler & 16 \\
\hline Alan bilgisi derslerinin yoğun olması (Eğitim bilimcilere göre) & 6 \\
\hline Alan bilgisi temel derslerinin kaldırılması & 5 \\
\hline Alan seçmeli ders önerileri için YÖK onayının alınması & 4 \\
\hline Alan bilgisi derslerinin ihtiyaca göre belirlenmemesi & 1 \\
\hline Meslek Bilgisi Derslerine ilişkin Görüşler & 17 \\
\hline Meslek bilgisi derslerinin uygulama saatlerinin azaltılması & 7 \\
\hline Meslek bilgisi derslerinin yoğun olması (Alan eğitimcilerine göre) & 5 \\
\hline Ek mesleki seçmeli dersler için YÖK onayı & 5 \\
\hline Alan, Meslek ve Genel Kültür Derslerinin Dengeli olması & 5 \\
\hline Genel Kültür Derslerinin Azaltılması & 1 \\
\hline İçeriğe iliş̧kin Öneriler & 33 \\
\hline İçerik öğrencilerin gereksinimlere göre belirlenmeli & 7 \\
\hline Zorunlu seçmeli dersler olmamalı & 5 \\
\hline Laboratuvar dersleri yeniden açılmalı & 4 \\
\hline Teorik derslere uygulama saatleri eklenmeli & 4 \\
\hline Alana uyarlanabilen dersler olmalı & 3 \\
\hline Dersler işe vuruk olmalı & 3 \\
\hline Alan dersleri arttırılmalı & 2 \\
\hline Öğretim elemanına göre ders açılmamalı & 2 \\
\hline Fakültenin bulunduğu bölgenin özellikleri de dikkate alınmalı & 1 \\
\hline Öğrenci gereksinimine göre ders seçebilmeli & 1 \\
\hline Dersleri dersin içeriği hakkında uzman öğretim elemanları vermeli & 1 \\
\hline
\end{tabular}

Tablo 2 incelendiğinde öğretim üyelerinin 2018 öğretmen yetiştirme lisans programlarındaki değişikliklere ilişkin görüşleri yer almaktadır. Bunlar, içeriğe, seçmeli derslere, alan, meslek ve genel kültür derslerinin uyumuna ve içeriğe ilişkin öneriler ile ilgilidir. Öğretim üyeleri, programlardaki ders sürelerinin azaltılmasını $(f=20)$, ders saati uygulama saati uyumsuzluğunu $(f=16)$, ders sayısının fazla olmasını $(f=15)$, içeriğin genelde aynı kalmasını $(f=14)$, bazı derslerin birbirinin tekrarı olmasını $(f=9)$, farklı bir seçmeli ders önermenin 
sınırlandırılmış olmasını $(f=1)$ eleştirmişleridir. Buna karşın programlara zorunlu eğitim sosyolojisi ve eğitim felsefesi derslerinin konulmasını $(f=1)$ olumlu bir gelişme olarak değerlendirmişlerdir. Bulgulara ilişkin doğrudan alıntı örnekleri aşağıda verilmiştir.

K11: Illk ders 10 dakika ya da 15 dakika ders yapabiliyorsun. İkinci ders çocuklar geldi, gitti, hop ders bitti, hadi güle güle... Dört saatlik ders bence uygulamayla beraber devam ettiğinde çok güzel ve keyifli geçen bir dersti.

K2: Bizde ders saati düşürülmemiş ama üç saat olarak kalmış. Bizim beklentimiz bunun artmasıydı.

K10: Kendi anabilim dalım için söyleyecek olursam içeriğin doldurulması çok zor. Ders sayısının düşürülmesi bazı derslerde iyi, bazı derslerde iyi değil. Mesela benim verdiğim bir ders haftada üç saatten iki saate düşürülmüş, onu mümkün değil bitiremem. Derslerin çoğu birbirinin tekrarı...

K22: Bazı anabilim dallarında problem yok ama bizim anabilim dalında fazla ders yükü var.

K2: Birleştirilmiş sınıflarda öğretim dersi zorunlu dersimizdi. Bu ders zorunluluktan çıkartılmış. Bakanlığın öngördüğü şeyler olabilir ya da YÖK'ün öngördüğü şeyler olabilir ama Türkiye'deki okulların \%30'u birleştirilmiş sınıf... 100 okul varsa bunun 30 tanesi birleştirilmiş...

K4: Eğitim sosyolojisi ve eğitim felsefesi derslerinin programa konulması çok güzel olmuş. Öğrencilerin bunları bilmesi gerekiyor. Olayın teorisini, altyapısını, toplumsal bağlamını çok iyi öğrenmesi gerekiyordu.

Öğretim üyeleri, programlardaki seçmeli derslerin sayısının artmasını ( $f=10$ ) ve seçmeli derslerin sayısının çok olmasını özgürlükçü bir yaklaşım $(f=7)$ olarak değerlendirmişlerdir. Buna karşın seçmeli dersler için öğretim elamanı sayısının yeterli olmamasını $(f=5)$, ek mesleki seçmeli dersler için YÖK onayı alınmasını $(f=4)$ sınırlandırıcı bir yaklaşım olarak görmektedirler. Bazı seçmeli derslerin hangi alan uzmanları tarafından verileceğinin belirsiz olmasını $(f=3)$, programlardaki uygulamaların azaltılmasını $(f=1)$ ve bazı derslerin sadece adının değişmesini $(f=1)$ olumsuz olarak değerlendirmişlerdir. Bulgulara ilişkin doğrudan alıntı örnekleri aşağıda verilmiştir.

K18: Seçmelilerin her dönem açılması ve her dönem çocukların istediği dersleri alabilmesi gibi özgürlükçü bir yaklaşımla başlanmış, ancak süreçte gayet sınırlamacı bir şekilde devam etmişler.

K6: Seçmeli dersler biraz daha özgürlükçü bir yapıda, istediğimiz dönem ders açabiliyoruz ama istediğimiz dersi de açabilme bağlamında daha özgürlükçü olmasını talep ederdim.

K7: Seçmeli dersler çok arttırılmış. Farklı bakış açısı, zenginleştirme, yönlendirme için daha işlevsel gözüküyor.

K1: Her alanda kendine, o alana özgü uzman bireylerin sayısının az olması ya da o alanda olup ama o alanda iyi çalışmamış olan hocaların yeterlilik düzeyinin düşük olması tabii ki burada ilgisiz derslerin açılabileceği problemini doğurabilir.

Öğretim üyeleri öğretmenlik alan bilgisi ve meslek bilgisi derslerine ilişkin farklı görüşlerini dile getirmişlerdir. Eğitimbilim alanında görev yapan öğretim üyeleri programlarda alan bilgisine ilişkin derslerin yoğun olduğunu $(f=6)$ belirtmişlerdir. Alan eğitimindeki öğretim üyeleri alan bilgisi temel derslerinin kaldırımasından $(f=5)$ rahatsız olduklarını dile getirmişlerdir. Alan seçmeli derslerinin YÖK onayına sunulmasının zorluk oluşturacağını $(f=4)$ belirmişlerdir. Alan derslerinin gereksinimlere göre belirlenmemesi $(f=1)$ de diğer bir eleştiri konusu olmuştur. Bulgulara ilişkin doğrudan alıntı örnekleri aşağıda verilmiştir.

K1: Alan bilgisi... Mesela, fizik, kimya, biyoloji derslerinin saati azaltılmış.

K19: Alan eğitiminden bir ders açmak için YÖK'e gönderip tekrardan gelmesi gerekiyor. Mevcut derslere siz yeni bir ders önermek istiyorsanı...

K7: Ders sayılarının da, ders sayı farklarının da azalmasından hareketle bence bizim oranımızın daha fazla olmasını beklerdim diye düşünürken, şu anda tam tersi meslek bilgisinin azaldığını düşünüyorum.

Meslek bilgisi derslerini veren öğretim üyeleri, meslek bilgisi derslerindeki uygulamalarının kaldırılmasını ya da azaltılmasını $(f=7)$ doğru bulmadıklarını belirtmişlerdir. Alan eğitiminde ders veren öğretim üyeleri meslek bilgisi derslerinin yoğun olduğunu( $f=5)$ dile getirmişlerdir. Öğretim üyeleri meslek bilgisi seçmeli derslerinin YÖK 
onayına sunulmasının sorun $(f=5)$ olabileceğini düşünmektedirler. Bu görüşlerin yanında alan, meslek ve genel kültür derslerinin dengeli $(f=5)$ olduğunu, genel kültür derslerinin azaltılması $(f=1)$ gerektiğini belirten öğretim üyesi de bulunmaktadır. Bulgulara ilişkin doğrudan alıntı örnekleri aşağıda verilmiştir.

K2: Meslek bilgisi ve alan bilgisi derslerini YÖK zorunlu gibi koymuş. Şu, şu, şu dersleri açacaksınız diye koymuş. Bunun dışında ekstra ders önerecekseniz en son biz karar veririz. O süreç bayağı uzun bir süreç... Önceden senato kararıyla hemen o dersi programımıza ekleyebiliyorduk.

K6: Bizde drama dersi var. Drama dersi önceden iki saat teorik, iki saat uygulamaydı. Şimdi iki saat teorik...

K21: Bizim öncelikle okuduğumuz kitaplarda bahsedildiği gibi \%50 alan, \%25 genel kültür, \%25 meslek bilgisi olması gerektiği... Mesela bir sınıf öğretmeni, ideal bir sınıf öğretmeni yetişmesi için böyle olması gerektiği vurgulanırdı. Bu rakam birbirine yakın bir rakam, şu andaki mevcut rakam yakın...

K8: Genel kültür dersleri biraz daha azaltılmış. Ben öğretmenlikte genel kültürün olmasının gerektiğini düşünüyorum. Genel kültüre yeterince sahip olmayan bir öğretmen başarılı olamaz.

Öğretim üyeleri programların içeriğine ilişkin önerilerde bulunmuşlardır. Öğretim üyelerine göre, içerik öğrencilerin gereksinimlere göre belirlenmeli $(f=7)$, programlarda zorunlu seçmeli dersler $(f=5)$ olmamalıdır. Laboratuvar dersleri yeniden açılmalı $(f=4)$, teorik derslere uygulama saatleri eklenmelidir $(f=4)$. Dersler, alana uyarlanabilen $(f=3)$ işe vuruk dersler $(f=3)$ olmalıdır. Alan derslerinin sayısı arttırılmalı ( $f=2)$ ve öğretim elamanlarına göre dersler $(f=2)$ açılmamalıdır. Dersler eğitim fakültelerinin bulunduğu bölgenin özellikleri de dikkate alınarak $(f=1)$ belirlenmelidir. Öğrenciler gereksinimine göre ders seçebilmeli $(f=1)$ ve dersleri, dersin içeriği hakkında uzman öğretim elemanları vermeli $(f=1)$. Bulgulara ilişkin doğrudan alıntı örnekleri aşağıda verilmiştir.

K8: Gelecek açısından öğretmenler için ihtiyacı ne? Bu ihtiyaç yeterince karşılanıyor mu? Karşılanmıyorsa nerede sorun var? O açıdan bakılması gerekir.

K32: Seçmeli ders mantığında anabilim dalındaki hocanın zenginliğinin yansıtması gerekirken zorunlu seçmeli mantığıyla seçmelilerimiz var.

K29: Programların en eksik yanlarından birisi uygulamaların azaltılmasıdır. Derslerin uygulamadan çok teoriye dönüştürülmesinin olumsuz bir etkisi olacağını düşünüyorum.

K1: Alan bilgisindeki fizik, kimya, biyolojinin ders saatlerinin arttırılması ve bu konuyla ilgili farklı derslerin açılması...

K17: Bu programları geliştirilirken onlar etkili olabilir. Farklılıkları program geliştirme uzmanı o bölgenin ihtiyaçlarına göre dersler koydurabilir. O bölgenin ihtiyaçlarını dikkate alarak programlar farklılaşabilir.

Öğretim üyelerinin öğretmen yetiştirme programlarının nitelikli öğretmen yetiştirmeye katkısına ilişkin görüşleri Tablo 3'te verilmiştir. Tablo 3 incelendiğinde öğretim üyelerinde, öğretmen yetiştirme lisans programlarının nitelikli öğretmen yetiştirmeye katkı sağlamayacağına yönelik görüşlerinin olduğu anlaşılmaktadır. Bunun nedeni olarak programlardaki ders saatlerinin azaltılmasını $(f=12)$, derslerdeki uygulamaların kaldırılmasını ya da azaltılmasını $(f=9)$, sadece teorik derslerin artmasını ( $f=7$ ), okul deneyimi dersinin kaldırımasını $(f=7)$, alanın gereksinimlerinin dikkate alınmadan programların hazırlanmasını $(f=6)$ ve öğretmenlik uygulamasının arttırılmamasını $(f=2)$ göstermişlerdir. Bulgulara ilişkin doğrudan alıntı örneği aşağıda verilmiştir.

K8: Nitelikli öğretmen yetiştirmekten çok... Biraz önce söylediğim gerekçelerden dolayı... Birincisi derslerin saatlerinin azaltılıp uygulamaya şey yapacak; ikincisi en önemlisi uygulama saatlerinin azaltılması, derslerin daha çok teoriye dönüşeceğini düşünüyorum. Diğer bir önemli şeyse, öğretmenler uygulama içinde öğreniyor, uygulama dönemlerinin azaltılması, okulla yeterince iletişimin bulunmaması... Bunların öğretmen yetiştirmenin niteliğini daha da azaltacağını düşünüyorum. Burada \%7'ye düştü. Bu düşünülüp bilimsel çalışma ve alanın ihtiyaçları dikkate alınarak yapılmış bir program değil. O anlamda da niteliği de daha düşürecek.

Öğretim üyeleri nitelikli öğretmen yetiştirilmesi için 2018 öğretmen yetiştirme lisans programları için önerilerde bulunmuşlardır. Öğretim üyelerine göre, öğretmenlik uygulamasının süresi arttırılmalı $(f=7)$, kapsamlı bir intiyaç analizi yapılmalı $(f=6)$ ve daha önce yapılmış araştırma sonuçları dikkate alınmalıdır $(f=5)$. 
Geliştirilen programlar değerlendirilmeli $(f=4)$, programları uygulayacak öğretim elemanları donanımlı $(f=4)$ hale getirilmelidirler. Uygulama okulları açılmalı $(f=4)$, eğitim fakültelerinin sayısı azaltılarak merkezi yerlere açılmalı, $(f=3)$. Öğretmen adaylarının entelektüel olması $(f=3)$ sağlanmalıdır. Lisans programlarında sınıf mevcutları azaltılarak $(f=3)$, sınıfların fiziki yapısı $(f=2)$ ve sınıftaki araç gereçler $(f=1)$, nitelikli öğretmen yetiştirmeye uygun hale getirilmelidir. Ayrıca, öğretmen adaylarının sosyo kültürel gelişimlerini destekleyici ortamlar $(f=1)$ olmalıdır. Bulgulara ilişkin doğrudan alıntı örnekleri aşağıda verilmiştir.

\section{Tablo 3}

Öğretmen Yetiştirme Programlarının Nitelikli Öğretmen Yetiştirmeye Katkısına ilişskin Görüşler

\begin{tabular}{lc}
\hline Temalar/Kodlar & $\mathbf{f}$ \\
\hline Programların Nitelikli Öğretmen Yetiştirmeye Katkı Sağlamaması & $\mathbf{4 2}$ \\
Ders saatlerinin azaltılması & 12 \\
Derslerdeki uygulama saatlerinin azaltılması ya da kaldıııması & 9 \\
Sadece teorik derslerin artması & 7 \\
Okul deneyimi dersinin kaldırılması & 7 \\
Alanın gereksinimlerinin dikkate alınmadan programların hazırlanması & 5 \\
Öğretmenlik uygulamasının arttırımaması & 2 \\
Nitelikli Öğretmen Yetiştirme Programları İçin Öneriler & 43 \\
Öğretmenlik uygulaması arttırılmalı & 7 \\
Programlar güncellenirken ihtiyaç analizi yapılmalı & 6 \\
Programlar güncellenirken araştırma sonuçlarının dikkate alınması & 5 \\
Program değerlendirme çalışmaları yapılmalı & 4 \\
Programları uygulayacak öğretim elemanları donanımlı olmalı & 4 \\
Uygulama okulları açımalı & 4 \\
Eğitim fakülteleri merkezi yerlere açılmalı & 3 \\
Entelektüel öğretmen yetiştirmeye dönük olmalı & 3 \\
Eğitim fakültelerinde sınıf mevcutları azaltılmalı & 3 \\
Fiziki mekânlar uygun hale getirilmeli & 2 \\
Araç gereçler yeterli olmalı & 1 \\
Öğretmen adaylarının sosyal kültürel gelişimlerini destekleyici ortamlar olmalı & 1 \\
\hline
\end{tabular}

K4: Çok samimi söylüyorum, (öğretmenlik uygulaması) her dönem olması gerekiyor. Çünkü alan bambaşka bir şey, uygulama bambaşka bir şey, her şeyi uygulamada öğreniyorsunuz.

K8: Sınıftaki öğrenci sayılarının azaltılması gerekiyor. Fiziki mekânların daha uygun hale getirilmesi gerekiyor. 80 kişilik sınıflarda uygulamalı bir sürecin olması çok mümkün değil. Araç, gereç ve donanımın iyi olması gerekiyor. Bakıyorsun çoğu okullarda (akıllı tahta) var. Buralarda eğitim fakültelerinde akıllı tahtalar yok. Laboratuvarlarda yeterli araçlar yok. Çok fazla sosyal, kültürel ortam olup düşünebildiği, tartışabildiği, özgürce kendini ifade edebildiği bir öğrencilerin sosyal, kültürel etkinliklere katılabildiği bir ortam yok. Öğretmen ne kadar donanımlı olursa o kadar güzel... Uygulama okullarının gerçekten olması gerekiyor. Her yere eğitim fakültesi açmak değil, daha çok merkezlere açılıp o öğretmenlerin operaya da gidebileceği, tiyatroya da gidebileceği, sanatsal etkinlikleri de yapabileceği, sosyal etkinliklere katılabileceği, okuyan bir öğretmen süreci olarak bakıyorum. Bir defa program iyi olacak. Programı alacağız ama program tek başına yeterli değil. Öğretim elemanları da nitelikli olacak. Hangi derslerden mutlu oluyorlar, hangi dersler daha verimli, hangi dersler niye verimsiz? Orada diyor, öğretmenler bu dersler çok alana katkı getirmiyor. Neden? Öğretim üyeleri şu dersleri işte etkili işlemiyor, anlatıyor, dersi uygulamalı yapmıyor. Araştırma sonuçları dikkate alınsa, zaten sorunlar görünüyor hangi alanda ders var? Öğrenciler nerede sorun yaşıyor? Uygulamayı daha çok arttırırsak daha başarılı olacak.

Öğretim üyelerinin okul uygulamalarına ilişkin görüşleri Tablo 4'te verilmiştir. Tablo 4'te okul uygulamaları kapsamında öğretmenlik uygulaması ve okul deneyimi derslerine ilişkin görüşler yer almaktadır. Öğretim üyeleri, öğretmenlik uygulaması dersinin süresinin yetersiz olduğunu ( $f=9$ ) belirtmişlerdir. İş yüklerinin fazlalığı nedeniyle akademik çalışmalara zamanlarının kalmadığını $(f=6)$, okullara gidip gözlem yapamadıklarını $(f=3)$ ifade etmişlerdir. Bu şekilde devam edilmesi halinde öğretmenlik uygulamasını almak istemeyeceklerini $(f=3)$ ve 
öğretim elemanlarının öğretmenlik uygulamasından uzaklaşabileceklerini $(f=2)$ vurgulamışlardır. Bulgulara ilişkin doğrudan alıntı örnekleri aşağıda verilmiştir.

K7: Bir öğretim elemanının akademik çalışması var, dersleri var ve aynı zamanda da staja giden grubu var. Ben zaman olarak bunlara dört kez vakit ayırdığımda diğer işlerimle ilgili aksamanın olmaması mümkün değil... Ders yükümün de çok olduğunu düşünsek, formül olarak işlemiyor.

\section{Tablo 4}

Öğretim Üyelerinin Okul Uygulamalarına ilişkin Görüşleri

\begin{tabular}{cc}
\hline Temalar/Kodlar & $\mathbf{f}$ \\
\hline Öğrretmenlik Uygulamasına ilişskin Görüşler & $\mathbf{2 3}$ \\
Öğretmenlik uygulamasının süresinin yetersiz olması & 9 \\
Öğretim elemanlarının iş yükünün fazla olması & 6 \\
İ̧̧yükü nedeniyle öğretim elemanlarının okullarda gözlem yapamaması & 3 \\
İ̧ yükü nedeniyle öğretim elemanlarının öğretmenlik uygulaması dersini istememesi & 3 \\
Uygulama süresinin fazla olması öğretim elemanlarını uygulamadan uzaklaştırması & 2 \\
Okul Deneyimi Dersine Illişkin Görüşler & $\mathbf{1 6}$ \\
Okul deneyimi dersinin 2018 programlarında yer almaması & 8 \\
Mesleği tanıma & 4 \\
Mesleğe hazıılık & 4 \\
Okul Uygulamalarına ilişkin Öneriler & $\mathbf{3 2}$ \\
Okul deneyimi dersinin daha erken dönemlere alınmaması & 10 \\
Öğretmenlik uygulamasının süresi arttırılmalı & 9 \\
Öğretmen yetiştirme lisans programları üç yıl teorik, bir yıı uygulama olmalı & 3 \\
Okul uygulamaları dersleri için öğretim elemanlarına da ücret verilmeli & 3 \\
Öğgretim elemanın ders sayısı azaltılmalı & 3 \\
Fakültelerde öğrenilenler okullarda uygulanmalı & 3 \\
Öğretmenlik uygulamaları ciddiye alınmalı & 1 \\
\hline
\end{tabular}

K8: Birçok öğretim elemanı da okullara gitmediği için birçok uygulamayı gözlemlemiyor, bazen dışarıda oluyor. Bu olumsuz. Bence de dört defa da gitsin, gidebilir. Bu iyi ama öğretim elemanının şöyle bir sıkıntısı var; birçok dersi var, farklı dersleri var. Sadece iki saatlik uygulama verip sekiz öğrenci için gittiğini düşündüğümüzde sekiz kere dört 32 defa okulda onu izleyecek.

Öğretim üyeleri öğretmenlik uygulaması dersi yanında okul deneyimi dersine ilişkin görüşler belirtmişlerdir. Öğretim üyeleri okul deneyimi dersinin 2018 programlarında yer almamasını $(f=8)$ eleştirmişlerdir okul deneyimi dersinin mesleği tanıma $(f=4)$ ve mesleğe hazırlık $(f=4)$ açısından önemli olduğunu ve kaldırılmaması gerektiğini belirtmişlerdir. Bulgulara ilişkin doğrudan alıntı örnekleri aşağıda verilmiştir.

K10: Okul deneyimi ve öğretmenlik uygulaması derslerinin uygulama kısmında yaşanılanları dikkate aldığımızda mutlaka okul deneyiminin birinci sınıfta olması gerektiğini önerdim.

K6: Ben ilk şeye takıldım, okul deneyimi dersinin ben birinci sınıfta, baharda artık geleceğini çok umut ediyordum. Oraya gelmediği gibi üçüncü sınıftan da kaldııımış. Bu, çocuğun laboratuvarı görmeden dördüncü sınıfa kadar alanı çok iyi laboratuvar ortamında görmeden gidip hadi öğretmenlik yap demek anlamına geliyor.

K21: Oysaki (okul deneyimi) birinci sınıftan başlasaydı ve ilerleyen dönemlerde yavaş yavaş gözlemler devam edip uygulamaya geçilseydi çocuklar hem seçtikleri mesleği tanıma hem de kendilerini hazır hissetme ya da bu iş bana göre değil, kısa yoldan dönmem lazım diyebilme tercihleri olacaktı.

Öğretim üyeleri okul uygulamalarının etkili bir şekilde yürütülmesi için önerilerde bulunmuşlardır. Öğretim üyeleri, okul deneyimi dersinin daha erken dönemde olması $(f=10)$ gerektiğini ifade etmişlerdir. Öğretim üyelerine göre, öğretmenlik uygulamasının süresi arttıılarak her dönem olmalı $(f=9)$ ya da üç yıl teorik bir yıl uygulama olmalıdır $(f=3)$. Uygulama gözlemleri için öğretim elemanına ücret verilmeli $(f=3)$, öğretim elemanın fakültedeki ders yükü azaltılmalı $(f=3)$, fakültelerde öğrenilenler okullarda uygulanmalı $(f=3)$ ve öğretmenlik uygulaması ciddiye alınmalıdır ( $f=1)$. Bulgulara ilişkin doğrudan alıntılar aşağıda verilmiştir. 
K7: Uygulama derslerini hemen bahardan başlatmayı, çocukların hemen gözleme gitmesini, ikinci sınıfta gözleme gitmesini, her dönem program içerisinde bir gözlem dersinin olup o ortamda bulunmalarını, okul ortamının havasını solumalarını isterim.

K2: Her gün okula gitsin, stajını yapsın. Koordinatörler olsun üniversitelerde. Fakültenin koordinatörleri olsun. Bu koordinatörün tek görevi bunları gözlemlemek olsun. Gitsin, onları yerinde kontrol etsin. Her anabilim dalı, bölümün birer koordinatörü olup bunları takip edebilir bence. Daha sağlıklı olur.

K27: Öğretmenlik uygulaması nasıl yapalım? Bence ilk üç yılda teorik dersler bitirilmeli. Son sınıf sadece uygulama dönemi olmalı. Öğretmenler, belki farklı bir bakış açısı olacak bu, son sınıfın tamamında staj yapabilir.

K5: Okulları tamamıyla bir laboratuvar durumuna dönüştürmeli, laboratuvara sürekli gidilmeli.

K8: Öğretmenlik uygulamasını çok ciddiye almak gerekiyor.

\section{Tartışma, Sonuç ve Öneriler}

2018 öğretmen yetiştirme lisans programlarının değerlendirilmesinin amaçlandığı bu çalışmada, öğretim üyeleri, 2018 öğretmen yetiştirme lisans programlarının hazırlanmasına, programlardaki değişikliklere, nitelikli öğretmen yetiştirmeye katkısına ve öğretim üyelerinin okul uygulamalarına ilişkin görüşlerine ve programlara yönelik önerilerine yönelik sonuçlar elde edilmiştir. Bu bölümde sonuçların ayrıntıları açıklanmış ve tartışılmıştır.

Eğitim programlarının geliştirilmesi, kapsamlı ve sürekli bir iş olması nedeniyle çalışmaların komisyon aracılığıyla yapılması yararlı görülmektedir. Bu komisyonlar program karar ve koordinasyon grubu, çalışma grubu ve danışma grubu olmak üzere üç gruptan oluşabilir. Program çalışma gruplarında yer alan öğretim elamanlarının alan uzmanı olmaları gerekmektedir (Demirel, 2015; Ornstein \& Hunkins, 2014). Bu grupların etkin bir şekilde çalışmaları için uzmanların liyakate göre ve şeffaf bir şekilde seçilmeleri gerekir. Seçilen uzmanların görüşlerine önem verilerek programlara yansıtılmalıdır. Ancak öğretim üyeleri 2018 öğretmen yetiştirme lisans programlarını geliştirme komisyonlarına davet edilen uzmanların liyakatlerini ve seçilme biçimlerini sorgulamaktadırlar. Programların tanıtım bölümlerinde de gerekli açıklamaların yapılmadığı görülmektedir. Program geliştirme komisyonları ile ilgili gerekli açıklamaların yapılmaması öğretim üyelerinin öğretmen yetiştirme lisans programlarına olumsuz bakış açısı geliştirmelerine neden olmuştur. Bu durum öğretim üyelerinin programları kabullenmelerini ve uygulamalarını zorlaştırabilir. Komisyonlara seçilme sürecinde ortaya çıkan sorunlar dışında, komisyonda yer alan öğretim üyelerinin de süreçte sorunlar yaşadıkları anlaşıımaktadır. Komisyondaki öğretim üyeleri program geliştirme sürecindeki önerilerinin dikkate alınmadığını, alınan kararların çoğulculuktan uzak olduğunu, hatta bu kararların daha sonra bilgilendirme yapılmadan değiştirildiğini belirtmişlerdir. Bunun yanında komisyon üyelerinin ağırlığının alan eğitimcilerinden oluştuğu görülmektedir. Bu durum alınan kararlarda alan eğitimcilerinin görüşlerinin baskın olarak programlara yansımasına neden olmuş olabilir. Kararların çoğulculuktan uzak olması programların nitelikli öğretmen yetiştirmeye uygunluğunu tartışmalı hale getirebilir.

Öğretim üyeleri programların geliştirilmeden önce değerlendirilmesi gerektiğini belirtmişlerdir. Program değerlendirmede, programın hedeflerinin, belirlenen içeriğin doğru ve öğrencilerin düzeyine uygun olup olmadığı, öğretim yöntemlerinin ve materyallerinin doğru seçilip seçilmediği, belirlenen hedeflere ne derece ulaşıldığı gibi sorulara yanıt aranır (Saylor \& Alexander, 1974). Bunun sonucunda programa devam edilmesi, programın gözden geçirilip geliştirilmesi ya da bitirilip yerine yeni bir programın geliştirilmesi gibi kararlar alınabilir (Ornstein \& Hunkins, 2004). Yeni programların hazırlanması için daha önce hazırlanan programların değerlendirilmesi ve programlardaki eksiklerin belirlenmesi gerekmektedir (Demirel, 2018; Ornstein \& Hunkins, 2004). Ancak 2018 öğretmen yetiştirme programlarının değişiklik gerekçeleri ve öğretim üyelerinin program geliştirme sürecine ilişkin görüşleri incelendiğinde, program değerlendirme çalışmaları yapılmadan yeni programların hazırlandığı anlaşılmaktadır. Programlarla ilgili açıklamalarda, programların güncellenmesi sürecinde MEB ve sivil toplum örgütlerince düzenlenen sempozyum, panel, çalıştay, açıkoturum, konferans gibi akademik etkinliklerin ve yapılan bilimsel çalışmaların sonuçlarının dikkate alındığı belirtilmiştir. ìlköğretim programlarında yapılan değişikliklerle uyum sağlanması ve programların Avrupa Yükseköğretim Alanı́na uygun hale getirilmesi gibi gerekçelerle yenilendiği ifade edilmiştir (YÖK, 2018). Programların yenilenebilmesi için önce tamamının kapsamlı bir şekilde değerlendirilmesi ve devamında değerlendirme sonuçları dikkate alınarak güncellenmesi gerekmektedir. Programlara ilişkin açıklamalar incelendiğinde öğretmen yetiştirme lisans 
programlarının ülke genelinde değerlendirilmediği, küçük çaplı araştırma sonuçlarının dikkate alındığı görülmektedir. Öğretmen yetiştirme lisans programlarının uygulanmaya başlandığı yıl, 2023 Eğitim Vizyon Belgesinde yenileneceği belirtilmiştir (MEB, 2018a). Programların uygulamaya başlanmasının ilk yılında yeniden değiştirileceğinin belirtilmesi öğretmen yetiştirme politikalarındaki eşgüdüm ve sürdürülebilirlik sorununu göstermektedir.

Yükseköğretim kurumu olarak üniversiteler özerk ve evrensel kurumlardır. Üniversitelerde mali, akademik ve yönetsel olmak üzere üç özerkliğin bulunması gerekir. Mali özerklik, üniversitenin kaynaklarını ve harcamalarını kendisinin yönetmesi durumudur (Erdem, 2013). Yönetsel özerklik, üniversitelerin kendi üyelerinin demokratik usulle oluşturdukları organlar eliyle yönetilmesi, denetlenmesi ve özlük haklarının güvencede olmasıdır (Aktan, 2008). Son olarak akademik özerklik ise, üniversitelerin araştırma-geliştirme alanını, eğitim-öğretim yaptığı programlarını ve ders içerikleri ile bilim insanlarını (öğretim elemanlarını) kendisinin seçebilmesi, kısacası neyi öğreteceğine ve neyi araştıracağına ve kimin tarafından araştırılıpöğretileceğine kurumun kendisinin karar verebilmesidir (Estermann, Nokkola \& Steinel, 2011). Akademik özerkliğin en önemli unsurları arasında üniversitelerin kendi öğretim programlarını ve ders içeriklerini belirleyebilmeleri yer almaktadır. Üniversite bünyesinde yer alan fen, edebiyat, iktisat ve mühendislik fakülteleri, programlarını kendileri oluşturmalarına karşın eğitim fakülteleri kendi özgün yapılarına uygun programlar hazırlayamamaktadırlar. Eğitim fakültelerinde YÖK tarafından merkezi olarak hazırlanan programlar uygulanmaktadır. Bazı öğretim üyeleri bu durumu eleştirmekte ve akademik özerkliğe aykırı bulmaktadırlar. Programların merkezi olarak hazırlanması öğretmen yetiştirmede ekolleşmeye, yaratıcı ve özgün modellerin ortaya konulmasına engel oluşturmaktadır. Bu durumun eğitim fakültelerinin akademik özerkliğine uygun olmadığı ve YÖK'ün genel bir çerçeve oluşturabileceği söylenebilir.

Öğretmen yetiştirme programlarındaki değişikliklere ilişkin görüşlerin de genelde olumsuz olduğu anlaşılmaktadır. Öğretim üyeleri, programlardaki ders sürelerinin azaltılmasını doğru bulmadıklarını belirtmişlerdir. Çünkü ders sürelerinin kısaltılması ve içeriğin aynı kalması ile derslerin amaçlarına ulaşılmasının zorlaşacağını belirtmişlerdir. Akademisyenlerin belirttikleri kaygılarının yanında ders sayısının fazla olması öğretim üyesi başına düşen ders yükünü artırabilir, bu durum öğretim üyelerinin araştırma yapmalarına engel oluşturabilir.

Eğitim felsefesi eğitimin ne yapması gerektiğini belirlemeye çalışan bir çaba olarak görülmektedir. Eğitim felsefesi eğitimin sorunlarını ve eğitime yöne veren kavram ve düşünceleri açıklamaya çalışır (Ergün, 2015; Sönmez, 2017). Bunun için öğretmenlerin eğitim üzerinde düşünmesi, gerçekliğe, insan doğasına ve topluma ilişkin kafa yorması gerekir (Gutek, 2016). Öğretmenlerin zihinsel olarak sorgulamaları ve felsefe yapabilmeleri için eğitim felsefesi gibi bir dersin olması ve bu dersin etkili bir şekilde yürütülmesi gerekir. Eğitim felsefesi dersi öğretmen adaylarının eğitime yönelik felsefi bir bakış açısı kazanarak mesleğini daha iyi yapmasını sağlayabilir (Aslan, 2014). Bu nedenle yapılan çalışmalarda eğitim felsefi dersinin eğitim fakültelerinin tüm bölümlerine konulması gerektiği belirtilmiştir (Duman ve Ulubey, 2008). 2018 öğretmen yetiştirme lisans programlarına zorunlu eğitim felsefesi ve eğitim sosyoloji dersleri konulmuştur. Öğretim üyeleri bu derslerin programlara konulmasını olumlu bir gelişme olarak değerlendirmektedirler. Bu dersler öğretmen adaylarının felsefi ve kültürel bakış açısı kazanmalarını sağlayabilecek önemli derslerdir (Eskicumalı, 2001). Eğitim sosyolojisi, öğretmen adaylarının mesleğe başladıklarında farklı toplumsal yapılarda ve kültürlerde ya da alt kültürlerde karşılaşabilecekleri sorunları çözmelerini, sorunların çözümünde bilinçli hareket etmelerini ve toplumsal yapıdaki farklı iliş̧kileri anlamalarını sağlayabilecek önemli bir derstir (Tezcan, 2016). Bu nedenle eğitim fakültelerinde eğitim sosyolojisi ve eğitim felsefesi derslerini özümseyerek katılan öğretmen adaylarının mesleklerinde ortaya çıkabilecek sorunları kolaylıkla çözmesi ve mesleklerinin gereklerini daha iyi yapması beklenebilir. Ancak Eğitim Sosyolojisi ve Felsefesi derslerinin verilmesi bu özelliklerin kazanılmasını garantilememektedir. Bunun için bu derslerde kuramsal bilginin yaşamla ilişkilendirmesi derslerin çok daha yararlı olmasını sağlayabilir.

Öğretim üyeleri programlardaki seçmeli derslerin sayısının artmasını özgürlükçü bir bakış olarak değerlendirirken, seçmeli dersler için öğretim elamanı sayısının yeterli olmayacağını düşünmektedir. Öğretim elemanı sayısının yeterli olmaması seçmeli olarak açılan derslerin "zorunlu seçmeli" derse dönüşmesine neden olabilir. Bu durum ise programların hedeflerine ulaşmasını zorlaştırabilir. Küçükahmet (2007) çalışmasında öğretmen yetiştirme programlarında bu soruna dikkat çekmiş, sınırlı sayıda seçmeli dersin açılması nedeniyle bu derslerin zorunlu seçmeliye dönüştüğünü belirtmiştir. 2018 öğretmen yetiştirme programlarında benzer bir durum ortaya çıkabilir. Bununla birlikte seçmeli meslek ve alan bilgisi derslerinin açılması için YÖK onayının 
gerekli olması bazı sorunları da beraberinde getirebilir. Bu konu ile ilgili öğretim üyeleri YÖK onayını doğru bulmadıklarını belirtmişlerdir. Yeni ders önerme konusunda ortaya çıkan süreç nedeniyle yeni ders önermeyebileceklerini, hatta bazı dersleri üniversite senatosu onayı ile genel kültür dersi gibi açılmasına yönelik çaba gösterebileceklerini söylemişlerdir. Bununla birlikte öğretim üyeleri sadece YÖK'ün önerdiği seçmeli dersleri açma eğiliminde olabilirler. Bu durumun, öğretim üyelerinin yeni yaratıcı dersler önermelerini olumsuz etkileyebileceği söylenebilir.

Öğretim üyeleri programdaki derslerin uzmanlık alanı olan öğretim elemanları tarafından verilmesi gerektiğini belirtmişlerdir. Küçükahmet (2007) öğretmen yetiştirme lisans programlarını değerlendirdiği çalışmasında, programdaki derslerin uzmanlığı olamayan öğretim elemanları tarafından verildiğini belirtmiştir. Öğretim üyeleri bu kaygıyı 2018 yılında geliştirilen program için de duymaktadırlar. Yıllar ve programlar değişse de öğretim üyelerinin uzmanlık alanı dışında ders verme durumları devam etmektedir. Nitelikli öğretmen yetiştirilebilmesi için bu uygulamanın çözüme kavuşturulması gerektiği düşünülmektedir.

2018 öğretmen yetiştirme programlarında dikkati çeken önemli değişikliklerden birisi bazı derslerin uygulama saatlerinin kaldırılmasıdır. Örneğin Öğretim Teknolojileri ve Materyal Tasarımı dersi iki saat kuramsal iki saat uygulamalı iken adı Öğretim Teknolojileri olarak değiştirilerek iki saat teorik bir derse dönüştürülmüştür. Drama dersleri genelde üç veya dört saat iken iki saate düşürülmüş ve uygulama konulmamıştır. Fen derslerindeki laboratuvar dersleri kaldırılmış ancak programlara ilişkin yer alan açıklamalarda derslerde uygulama yapılabileceği belirtilmiştir. Öğretmenlik mesleğine hazırlanmanın en iyi yolu derslerin uygulamalı yapılmasıdır. Derslerdeki uygulamaların arttırılması yerine kaldırılması öğretmenlerin nitelikli bir şekilde yetiştirilmelerini olumsuz etkileyeceği düşünülmektedir. Küçükahmet (2007) çalışmasında 2007 öğretmen yetiştirme lisans programlarında öğretmenlik meslek bilgisi derslerindeki uygulamaların azaltılmasını eleştirilmiştir. Ancak 2007 programlarındaki uygulamaların azaltılması nedeniyle eleştirilirken 2018 öğretmen yetiştirme programlarında aynı derslerin uygulamalarının tamamen kaldırılması oldukça düşündürücüdür. Bu durum öğretmenlik mesleği ve öğretmenin niteliği açısından önemli bir eksiklik olarak değerlendirilebilir. Bu nedenle öğretim üyeleri öğretmen yetiştirme lisans programlarının nitelikli öğretmen yetiştirmeye katkı sağlamayacağını düşünüyor olabilirler.

Öğretim üyeleri öğretmenlik alan ve meslek bilgisi derslerine ilişkin farklı görüşler dile getirmişlerdir. Eğitim bilimleri alanında görev yapan öğretim üyeleri programlarda, alan bilgisine ilişkin derslerin yoğun olduğunu belirtirken tam tersi bir şekilde alan eğitiminde ders veren öğretim üyeleri meslek bilgisi derslerinin daha yoğun olduğunu belirtmişlerdir. 1997 ve 2006 yılında öğretmen yetiştirme programlarında yapılan değişikliklerde alan, meslek ve genel kültür dersi oranlarının birbirine yakın olduğu, geliştirilen döneme göre farklılaştığı söylenebilir. Örneğin, 1997 yapılanmasında öğretmen yetiştirme programlarının \%50’sini alan bilgisi, \%30’unu öğretmenlik meslek bilgisi, \%20'sini genel kültür dersleri oluştururken (YÖK, 1997), 2006 öğretmen yetiştirme programlarında \%50-60'ını alan bilgisi, \%25-30'unu meslek bilgisi ve \%15-20'sini genel kültür dersleri oluşturmaktadır (YÖK, 2007). 2018 yılında geliştirilen programların ise \%45-50'sini alan eğitimi dersleri, \%3035'ini meslek bilgisi dersleri, \%15-20'sini ise genel kültür dersleri oluşturmaktadır (YÖK, 2018). 1997, 2006 ve 2018 programları incelendiğinde alan bilgisi derslerinin \%50 düzeyinde, meslek bilgisi derslerimin \%30 genel kültür derslerinin ise \%20 civarında olduğu söylenebilir. Derslerin ağırlıklarında oransal olarak çok fazla bir değişim olmasa da öğretim üyeleri ders sayılarının ve sürelerin azalması nedeniyle ve kendi uzmanlık alanları olan derslerin daha önemli olduğunu varsayarak derslerin ağırlığının azaldığını düşünmüş olabilirler.

Öğretmen adayları, mesleğe başlamadan önce okul deneyimi ve öğretmenlik uygulaması derslerinin uygulamalarında kendilerini mesleki olarak sorgulama ve eksikliklerinin farkına varma olanağı bulurlar. Bu dersler öğretmen adaylarının mesleğe ve okula hazırlanmalarına imkân vermesi açısından çok önemlidir (Akpınar, Çolak \& Yiğit, 2012; Kavas ve Bugay, 2009). Okul uygulamalarının önemi Milli Eğitim Şura kararlarına da yansımıştır. Örneğin 18. Mili Eğitim Şurası'nda öğretmenlik uygulamasının öğretim elemanlarının ve öğretmenlerin rehberliğinde aday öğretmenlik süreci gibi öğretim yılı boyunca yapılması gerektiğine yönelik karar alınmıştır (MEB, 2010). Bununla birlikte alanyazında öğretmenlik uygulaması ile ilgili yapılan çalışmalarda öğretmenlik uygulaması dersinin daha uzun süreye yayılması gerektiği ve mevcut sürenin yetersiz olduğu vurgulanmıştır (Aslan \& Sağlam, 2018; Aydın, Selçuk \& Yeşilyurt, 2007; Baskan, Aydın \& Madden, 2006; Güzel, Cerit-Berber \& Oral, 2010; Şimşek, Alkan \& Erdem, 2013). Bu araştırmada öğretim üyeleri benzer şekilde öğretmenlik uygulaması dersinin uygulamasının bir yıl ya da her dönem olması gerektiğini belirtmişlerdir. Ancak. 2018 öğretmen yetiştirme lisans programları incelendiğinde daha önce yapılan çalışmaların ve Şura kararlarının dikkate alınmadığı söylenebilir. Araştırmada öğretim üyeleri öğretmenlik uygulaması dersinin 
süresinin arttırılması hatta bir dönemin tamamında okulda uygulamaya katılması ya da her dönem öğretmenlik uygulamasının olması gerektiğini belirtmişlerdir.

Öğretmenlik uygulaması dersinin amacına ulaşabilmesi için öğretmen adaylarının öğretmenler ve öğretim üyeleri tarafından gözlemlenmesi, eksik yönlerinin düzeltilmesi ve iyi yapılan uygulamaların devamının sağlanması gerekmektedir. Öğretmenler, öğretmen adayları ile birlikte derse girmeleri nedeniyle gözlem yapma konusunda sorun yaşadıklarını ifade etmişlerdir. Öğretim üyeleri ise ders yüklerinin fazlalığı, derslerin uygulamalarla uygun planlanmaması nedeniyle gözlem yapma konusunda sorun yaşadıklarını belirtmişlerdir. Alanyazında yapılan çalışmalar bu sonucu destekler niteliktedir. Çepni, Aydın ve Şahin (2015) tarafından yapılan çalışmada öğretmenlik uygulaması dersi kapsamında öğretmen adaylarının alanda yeterince gözlenmediği, uygulama günleri ile öğretim üyelerinin programlarının uyumlu olmadığı belirlenmiştir. Öğretim üyeleri, ders yüklerinin fazla olması nedeniyle gözlem yapamadıklarını belirtmişlerdir (Aytaçlı, 2012; Kıyıcı \& Horzum, 2015; Kirksekiz, Uysal, İşbulan, Akgün, Kiyici \& Horzum, 2015). Öğretim elemanlarının sorumlu olduğu öğretmen adayı sayısının fazla olması nedeniyle sorumluluklarını yeterince yerine getirememektedirler (Aslan \& Sağlam, 2018; Ilin, 2014; Topkaya, Tokcan \& Kara, 2012). Öğretim elemanlarının bir uygulama öğrencisini en az dört kez, sekiz öğrenciyi toplam 32 kez uygulama esnasında izlemesi beklenmektedir (MEB, 2018b). Araştırma sonucu ile alanyazındaki diğer çalışmaların sonuçları birlikte değerlendirildiğinde, öğretim elemanlarının iş yükünün fazla olduğu bölümlerde öğretmenlik uygulaması dersinin gereklerini yerine getirmelerinin zorlaştığı anlaşımaktadır. Öğretmenlik uygulamalarında okuldaki uygulama öğretmeni hatta uygulama yapılan okulun yöneticilerine dahi ücret ödenirken uygulama öğretim elemanlarına ücret ödenmemesi öğretim elemanlarının bu görevleri üstlenmelerinde isteksiz davranmalarına neden olabilir.

Okul deneyimi dersi öğretmen adayının mesleği ile ilk kez karşılaştığı bir ders olması nedeniyle, öğretmenlik uygulaması dersi kadar önemli bir derstir. Öğretmen adayının bu derste mesleği ile ilgili edineceği ilk izlenimler ileride nasıl bir öğretmen olacağını büyük oranda şekillendirmektedir. Yapılan bir çalışmada, okul deneyimi dersinin okul öncesi öğretmeni adaylarının öğretmenlik mesleğine ve kendi alanlarına yönelik farkındalıklarını arttırdığı ortaya konulmuştur (Ekinci ve Tican-Başaran, 2015). Ancak birçok öğretmen adayı bu dersi ve Öğretmenlik Uygulaması Dersini kolay ve önemsiz dersler olarak görmektedir. Bu nedenle okul deneyimi dersi kapsamında sorumluluklarını yerine getirmemektedirler (Akdemir, 2013). Kimi durumlarda uygulama öğretmenleri ve öğretim elemanlarının öğretmen adaylarının sorumluluklarını yerine getirme düzeyine bakmaksızın yüksek ve standart notlar vermeleri söz konusu olabilmektedir. Bu derse önem verilmemesine başka bir örnek de program güncelleme süreçlerinde dersin ağırlığının azaltılması gösterilebilir. 1997 öğretmen yetiştirme programlarında Okul Deneyimi I ve II dersleri varken, 2007 yılında Okul Deneyimi II dersi kaldırımıştır. Küçükahmet (2007) Okul Deneyimi II dersinin kaldırılmasını eleştirmiş bu dersin öğrencilerin okulu tanımları için fırsat olarak görüldüğünü belirtmiştir. 2018 öğretmen yetiştirme programlarında ise okul deneyimi dersi tamamen kaldırımıştır. Böylece öğretmen adaylarının mesleği tanıma ve mesleğe hazırlanma fırsatları azaltılmıştır. Bu çalışmada öğretim üyeleri ile yapılan görüşmelerde okul deneyimi dersinin kaldırılması eleştirilmiştir. Çünkü okul deneyimi dersinde öğrenciler mesleğe uygun olup olmadıkları, bu bağlamda mesleğe devam etme ya da bırakma konularında karar verebilmektedirler. Bu nedenle okul deneyimi dersinin kaldırıması bir yana erken dönemlerde yer almasının öğretmenlik mesleğine yönelik erken deneyimlerin kazanılması açısından son derece yararlı olacağı düşünülmektedir.

2018 öğretmen yetiştirme lisans programlarının değerlendirilmesinin amaçlandığı bu çalışmada, öğretim üyeleri, programlarının program geliştirme ilkelerine uygun bir şekilde hazırlanmadığını belirtmişlerdir. Bu sonuç Türkiye gibi oldukça köklü bir program geliştirme kültürüne sahip bir ülke için olumsuz bir tablodur. Öğretmen yetiştirme lisans programları nitelikli öğretmen yetiştirmenin en önemli araçlarıdır. Bu araçlar, doğru bir program geliştirme süreci ile hazırlanırlarsa, ülkenin uzak hedeflerine ulaşılması daha kısa ve daha istenilen şekilde olacaktır.

2018 öğretmen yetiştirme programlarının merkezi olarak geliştirilmesi, paydaşların görüşlerinin programlara tam olarak yansıtılmaması, program geliştirme sürecinde oluşturulan komisyonlarda görev alan öğretim elemanlarının göreve davetlerinde şeffaflık olmaması ve programların, program değerlendirme çalışması yapılmadan oluşturulması eleştirilmiştir. Bu eleştiriler dikkate alınarak, daha sonraki öğretmen yetiştirme programları oluşturulurken en alt kademeden en üst kademeye kadar tüm paydaşların görüşleri alınmalıdır. Komisyonlarda alınan kararlarda çoğulcu bir anlayış hâkim olmalıdır. YÖK'ün program geliştirme sürecindeki rolü azaltılmalı ve eğitim fakültelerinde görev yapan öğretim elemanlarının akademik uzmanlıkları öğretmen yetiştirme programlarına yansıtılmalıdır. Fakültelerin öğretmen yetiştirme kültürlerinin oluşmasına izin 
verilmelidir. Programların pilot uygulamaları yapılarak işlemeyen kısımlar düzeltilmelidir. Ardından uygulamaya başlanmalıdır. Uygulanan programlar süreçte ve sonuçta kapsamlı olarak değerlendirilerek yeniden düzenlenebilir.

Öğretmen yetiştirme lisans programlarında diğer bir eleştiri konusu derslerin sürelerinin kısaltılması, yeni açılacak alan ve meslek bilgisi seçmeli derslerinin YÖK onayına bağlı olması ve ders sayısının en fazla altı olmasıdır. Bu durum öğretim elemanlarının yeni ders önermelerini, ders sürelerinin kısa olması da ders içeriğinin öğretimini zorlaştırmaktadır. Bu nedenle seçmeli ders önerilmesi amacıyla YÖK onayı kaldırılmalı, derslerin süreleri artırımalıdır. Derslerle ilgili diğer önemli bir konu derslerdeki uygulamaların kaldırılmasıdır. Öğretmenlik mesleğine yönelik becerilerin kazanılmasında derslerin uygulamalı olması önemlidir. Öğretmen adaylarına derslerin teorik kısımlarında öğrendiklerini uygulama imkânı sağlanmalıdır.

Öğretmenlik mesleği becerilerinin kazanıldığı önemli dersler okul uygulamalarıdır. Programda okul deneyimi dersi kaldırılmış, öğretmenlik uygulaması dersinin süresi iki katına çıkarılmıştır. Ancak öğretim üyeleri bu artışı yeterli görmemişler. Bu dersin, öğretmen adaylarının bir dönemin tamamında sadece uygulama yapabileceği şekilde düzenlenmesinin yararlı olacağı düşünülmektedir. Öğretmenlik uygulaması dersi kapsamında, bir öğretim elamanından en fazla sekiz öğretmen adayına danışmanlık yapması ve her birini dört kez gözlemlenmesi istenmiştir. Ancak sekiz öğrencinin dört farklı kez gözlemlenmesi öğretim elemanının 32 kez okula gitmesini gerektirmektedir. Bu durum öğretim elemanlarının iş yükü göz önünde bulundurulduğunda gerçekçi görünmemektedir. Bu nedenle düzenlemenin gözden geçirilmesi gerekir. Okul deneyimi dersi de öğretmenlik uygulaması kadar önemli bir derstir. Çünkü bu derste öğretmen adayları mesleği tanımakta ve öğretmen olup olmamaya karar vermektedirler. Dersin kaldırılması mesleği tanıma ve mesleğe hazırlık açısından sorunlara yol açabilir. Bu nedenle öğretmenlik uygulaması dersi yeniden programlara konulabilir.

Bu araştırma, Türkiye'nin batı bölgesinde bulunan bir üniversitenin eğitim fakültesinde görev yapan öğretim üyeleri ile gerçekleştirilmiştir. Çalışma Türkiye'nin farklı bölgelerindeki eğitim fakültelerinde görev yapmakta olan öğretim elemanları ile yeniden yapılabilir. Öğretmen yetiştirme programlarının uygulanması sürecinde ve ilk dört yılın sonunda program değerlendirme çalışmaları yapılarak elde edilen sonuçlar bu araştırmanın sonuçlarıyla karşılaştırılabilir.

\section{Bilgilendirme}

Bu çalışma 11-13 Ekim 2018 tarihlerinde Kars Türkiye'de gerçekleştirilen 6. Uluslararası Eğitim Programları ve Öğretim Kongresinde sözlü bildiri olarak sunulmuştur. 


\section{References}

Akpınar, M., Çolak, K. \& Yiğit, E. Ö. (2012). Öğretmenlik uygulaması dersi kapsamında sosyal bilgiler öğretmeni adaylarının yeterliklerine yönelik uygulama öğretmenlerinin görüşleri. M.Ü. Atatürk Eğitim Fakültesi Eğitim Bilimleri Dergisi, 36, 41-67.

Aktan, C. (2008). Akademik özerklik. Retrieved from http://www. canaktan.org/egitim/universite-reform/akaozerklik.htm\#_edn5.

Akdemir, A. S. (2013). Türkiye'de öğretmen yetiştirme programlarının tarihçesi ve sorunları. Electronic Turkish Studies, 8(12), 15-28.

Aslan, Ö. M. (2014). Eğitim felsefesi dersinin okul öncesi öğretmen adaylarının felsefi tercihlerine ve eleştirel pedagojiye yönelik görüşlerine olan etkisi. Elektronik Sosyal Bilimler Dergisi, 13(48), 1-14.

Altunya, N. (2005). Köy enstitüsü sistemine toplu bir bakıs. Ankara: Kelebek Matbaası.

Aslan, M., \& Sağlam, M. (2018). Öğretmenlik uygulaması dersinin öğretmen adaylarının görüşlerine göre değerlendirilmesi. Hacettepe Üniversitesi Eğitim Fakültesi Dergisi, 33(1), 144-162.

Ataman, A. (1998). Eğitim fakültelerinin yeniden yapılanmasının düşündürdükleri. Eğitim Yönetimi, 4(15), 263270.

Atanur-Baskan, G. (2001). Öğretmenlik mesleği ve öğretmen yetiştirmede yeniden yapılanma. Hacettepe Üniversitesi Eğitim Fakültesi Dergisi, 20, 93-102.

Ataünal, A. (1987, Haziran). Yükseköğretim Kurulu'nun ilkokul öğretmeni yetiştirmeye ilişkin projeksiyonu", Öğretmen Yetiştiren Yükseköğretim Kurumlarının Dünü-Bugünü-Geleceği Sempozyumu, Ankara.

Ataünal, A. (1994). Türkiye'de ilkokul öğretmeni yetiştirme sorunu ve ABD, Ingiltere, Fransa ve Almanya'daki çağdaş uygulama ve eğilimler (1923-1994). Ankara: MEB Yükseköğretim Genel Müdürlüğü.

Altheide, D. L., \& Johnson, J. M. (2011). Reflections on interpretive adequacy in qualitative research. The SAGE Handbook Of Qualitative Research, 4, 581-594.

Aydın, S., Selçuk, A., \& Yeşilyurt, M. (2007). Öğretmen adaylarının "okul deneyimi II” dersine ilişkin görüşleri (Yüzüncü Yıl Üniversitesi örneği). Yüzüncü Yıl Üniversitesi, Eğitim Fakültesi Dergisi, 4(2), 75-90.

Baskan, G., Aydın, A., \& Madden, T. (2006). Türkiye'deki öğretmen yetiştirme sistemine karşılaştırmalı bir bakış. Çukurova Üniversitesi Sosyal Bilimler Enstitüsü Dergisi, 15(1), 35-42.

Cicioğlu, H. (1983). Türkiye Cumhuriyeti'nde ilk ve orta öğretim (Tarihi Gelişimi) Ankara: AÜ Dil ve TarihCoğrafya Fakültesi Yayınları.

Cruickshank, D. R., Bainer, D., Cruz J., Giebelhaus, C., McCullough, J. D., Metcalf, K. K. \& Reynolds, R. (1996). Preparing America's teachers. Bloomington: The Phi Delta Kappa Educational Foundation.

Çepni, O., Aydın, F., \& Şahin, V. (2015). Coğrafya öğretmen adaylarının öğretmenlik uygulaması dersine ilişkin görüşleri. Cumhuriyet Uluslararası Eğitim Dergisi, 4(1), 35-49.

Darling-Hammond, L. (2006). Powerful teacher education: Lessons from exemplary programs. San Francisco: Jossey-Bass.

Demirel, Ö. (2018). Eğitimde program geliştirme: Kuramdan uygulamaya. Ankara: PEGEM Yayıncılık.

Duman, B. \& Ulubey, Ö. (2008). Öğretmen adaylarının benimsedikleri eğitim felsefelerinin öğretim teknolojilerini ve interneti kullanma düzeylerine etkisi ile ilgili görüşleri. Muğla Üniversitesi Sosyal Bilimler Enstitüsü Dergisi, 20, 95-114.

Ekinci, N. \& Tican-Başaran, S. (2015). Okul deneyimi dersinin öğrencilerin öğretmenlik algılarına etkisi. MSKÜ Eğitim Fakültesi Dergisi, 2(1), 13-24.

Erdem, A. R. (2013). Üniversite özerkliği: Mali, akademik ve yönetsel açıdan yaklaşım. Journal of Higher Education \& Science/Yüksekögretim ve Bilim Dergisi, 3(2), 97-107.

Erden, M. (1998). Eğitimde program değerlendirme. ( $3^{\text {rd }}$ edition). Ankara: PEGEM Akademi Yayıncılık. 
Özgür Ulubey, Semra Başaran - Uluslararası Eğitim Programları ve Öğretim Çalışmaları Dergisi, 9(2), 2019, 263-300

Ergün, M. (2015). Eğitim felsefesi ( $5^{\text {th }}$ edition). Ankara: PEGEM Akademi Yayınları.

Eskicumalı, A. (2001). Öğretmen eğitimi ve eğitim sosyolojisi dersleri. Sakarya Üniversitesi Eğitim Fakültesi Dergisi, 1(1), 30-37.

Estermann, T., Nokkola, T., \& Steinel, M. (2011). University autonomy in Europe II: The scorecard. Brussels: European University Association.

Gözütok, F. D. (2001). Program değerlendirme. In M.Gültekin (Ed.) Öğretimde planlama ve değerlendirme (pp. 175-190).Eskişehir: Anadolu Üniversitesi Yayını.

Gutek, G. L. (2014). Eğitime felsefi ve ideolojik yaklaşımlar (N. Kale, Trans.). Ankara: Ütopya Yayınları.

Güzel, H., Cerit-Berber, N., \& Oral, İ. (2010). Eğitim fakültesi uygulama okulları işbirliği programında görevli öğretmenlerin ve öğretim elemanlarının öğretmenlik uygulamasına yönelik görüşleri. Kastamonu Eğitim Dergisi, 18(1), 19-36.

Ilin, G. (2014). Practicum from the ELT student-teachers' eye: Expectations and gains. International Journal of Language Academy, 2(1), 191-207.

Kavas, A. B., \& Bugay, A. (2009). Öğretmen adaylarının hizmet öncesi eğitimlerinde gördükleri eksiklikler ve çözüm önerileri. Pamukkale Üniversitesi Eğitim Fakültesi Dergisi, 25(25), 13-21.

Kavcar, C. (2002). Cumhuriyet döneminde dal öğretmeni yetiştirme. Ankara Üniversitesi Eğitim Bilimleri Fakültesi Dergisi, 35(1-2), 1-14.

Kirksekiz, A., Uysal, M., İşbulan, O., Akgün, Ö., Kiyici, M., \& Horzum, M. (2015). Okul deneyimi ve öğretmenlik uygulaması derslerine eleştirel bir bakış: Problemler, beklentiler ve çözüm önerileri. Bartın Üniversitesi Eğitim Fakültesi Dergisi, 4(2), 433-451.

Küçükahmet, L. (2007). 2006-2007 öğretim yılında uygulanmaya başlanan öğretmen yetiştirme lisans programlarının değerlendirilmesi. Journal of Turkish Educational Sciences, 5(2), 203-219.

LeCompte, M. D., \& Goetz, J. P. (1982). Problems of reliability and validity in ethnographic research. Review of educational research, 52(1), 31-60.

MEB [MoNE]. (1995). Türkiye'de öğretmen yetiştirme (1948-1995). Ankara: MEB Basımevi.

MEB [MoNE]. (2010). 18. Millî Eğitim Şûrası kararları: Öğretmenin yetiştirilmesi, istihdamı ve mesleki gelişimi. Retrieved from https://ttkb.meb.gov.tr/meb_iys_dosyalar/2017_09/29170222_18_sura.pdf.

MEB [MoNE]. (2018a). 2023 eğitim vizyonu. Retrieved from http://2023vizyonu.meb.gov.tr/.

MEB [MoNE]. (2018b). Uygulama öğrencilerinin Milli Eğitim Bakanlığına bağlı eğitim öğretim kurumlarında yapacakları öğretmenlik uygulamasına ilişkin yönerge. Retrieved from (12.08.2018) http://oygm.meb.gov.tr/meb_iys_dosyalar/2018_06/25172143_YYnerge.pdf

Merriam, S. B. (2013). Nitel araştırma: Desen ve uygulama için bir rehber (S. Turan, Trans.). Ankara: Nobel Yayıncilık.

Oğuzkan, F. (1983). Orta dereceli okul öğretmenlerinin yetiştirilmesi, Cumhuriyet döneminde eğitim. İstanbul: Milli Eğitim Basımevi.

Ornstein, A. C., \& Hunkins, F. P. (2014). Eğitim programı. Temeller, ilkeler ve sorunlar (A Arı, Trans.) Konya: Eğitim Yayınevi.

Ornstein, A. C. and Hunkins, F. P. (2004). Curriculum foundations, principles and issues. $\left(4^{\text {th }}\right.$ ed.) Boston: Pearson Education.

Öztürk, C. (2005). Türkiye'de dünden bugüne öğretmen yetiştiren kurumlar. İstanbul: Milli Eğitim Bakanlığı Yayınları.

Öztürk, C. (1998). Cumhuriyet döneminde öğretmen yetiştirme. 75. yılda eğitim. İstanbul: Türkiye Ekonomik ve Toplumsal Tarih Vakfı Yayınları.

Öztürk, C. (1996). Atatürk devri öğretmen yetiştirme politikası. Ankara: Türk Tarih Kurumu Basımevi. 
Özgür Ulubey, Semra Başaran - Uluslararası Eğitim Programları ve Öğretim Çalışmaları Dergisi, 9(2), 2019, 263-300

Özalp, R. A. \& Ataünal, A. (1977). Türk milli eğitim sisteminde düzenleme teşkilatı. İstanbul: Milli Eğitim Basımevi.

Patton, M. Q. (2014). Nitel araştırma ve değerlendirme yöntemleri (M. Bütün ve S. B. Demir, Trans.). Ankara: PEGEM Akademi.

Safran, M. (2014, Mayıs). Eğitim fakülteleri, öğretmen yetiştirme süreci ve yeni arayışlar. 4. Öğretmen Yetiştirme Politika ve Sorunları Uluslararası Sempozyumu. Ankara. Retrieved from http://www.egitim.hacettepe.edu.tr/belge/ispite_2014.pdf

Saylor, J. G., \& Alexander, W. M. (1974). Planning curriculum for schools. New York: Holt, Rinehart and Winston.

Sönmez, V. (2005). Eğitim felsefesi (14 ${ }^{\text {th }}$ edition). Ankara: Anı Yayıncılık.

Şahin, M. (2006). Avrupa Birliği ülkelerinde ve Türkiye'de öğretmen yetiştirme sistemlerinin karşılaştırması. Unpublished PhD Thesis, İnönü University, Malatya Turkey.

Şimşek, S., Alkan, V., \& Erdem, A. R. (2013). Öğretmenlik uygulamasına ilişkin nitel bir çalışma. Pamukkale Üniversitesi Eğitim Fakültesi Dergisi, 34(34), 63-73.

Tambağ, H. (2007). Ortaöğretim alan öğretmenliği tezsiz yüksek lisans programına devam eden öğrencilerin bu programa ilişkin görüşleri nelerdir? Unpublished Master Thesis, Yıldız Teknik University, İstanbul.

TEDMEM, (2014). 2014 Eğitim değerlendirme raporu. Ankara: Türk Eğitim Derneği Yayınları.

Tezcan, M. (2016). Eğitim sosyolojisi (16 ${ }^{\text {th }}$ edition). Ankara: Anı Yayıncılık

Topkaya, Y., Tokcan, H., \& Kara, C. (2012). Öğretmenlik uygulaması dersi hakkında sosyal bilgiler öğretmeni adaylarının görüşleri. The Journal of Academic Social Science Studies, 5(7), 663-678.

Uçan, A. (1982). Gazi yüksek öğretmen okulu müzik bölümü müzik alanı birinci yıl yetişeğinin (programının) değerlendirilmesi. Unpublished PhD Thesis, Hacettepe University, Ankara.

Yıldırım, A. (2011). Öğretmen eğitiminde çatışma alanları ve yeniden yapılanma. Uluslararası Eğitim Programları ve Öğretim Dergisi, 1(1), 1-17.

Yıldırım, A. \& Şimşek H. (2013). Sosyal bilimlerde nitel araştırma yöntemleri (11 ${ }^{\text {th }}$ edition). Ankara: Seçkin Yayıncilık.

YÖK [HEC]. (1998). Eğitim fakülteleri öğretmen yetiştirme programlarının yeniden düzenlenmesi. Ankara.

YÖK [HEC]. (2007). Öğretmen yetiştirme ve eğitim fakülteleri (1982-2007). Ankara: Meteksan.

YÖK [HEC]. (2018). Öğretmen yetiştirme lisans programları Retrieved from https://www.yok.gov.tr/Documents/Kurumsal/egitim_ogretim_dairesi/Yeni-Ogretmen-Yetistirme-LisansProgramlari/AA_Sunus_\%200nsoz_Uygulama_Yonergesi.pdf. 
